\title{
Playing Legislative Catch-Up in 2010 With A Growing, High-TeCh Phenomenon: EVOLVING STATUTORY APPROACHES FOR ADDRESSING TEEN SEXTING
}

\author{
By Clay Calvert, Kara Carnley Murrhee \& Jackie Marie Steve \\ Volume XI - Fall 2010 \\ Copyright (C) Pittsburgh Journal of Technology Law and Policy
}

\begin{abstract}
This article analyzes and critiques legislation adopted by states in 2010 to address the burgeoning phenomenon of teen sexting. Sixteen different states in 2010, stretching from California to New York, considered bills or resolutions designed to address, in one manner or another, teen sexting. By early November 2010, sexting bills had been signed into law by the governors of Arizona, Connecticut, Illinois and Louisiana. To illustrate the differences, as well as the strengths and weaknesses among the new sexting laws, the article applies each of them to the facts of realistic sexting scenario. Significantly, this analysis of the laws through the lens of hypothetical fact pattern reveals that the low-tech, downstream transmission of hard copies of sexual images of minors - images that were initially transmitted by cell phones by minors - appears to escape the reach of all of the 2010 sexting laws. The article argues that this gap or loophole in the new laws should be addressed by amending them. Ultimately, the article demonstrates a distinct lack of uniformity across the sexting statutes adopted in 2010. For instance, even when it comes to what would appear to be the most objective element of the offense of sexting - the maximum age of the possible perpetrator - there is disagreement. Such disparity creates an uneven patchwork of legislation that fails to give minors proper notice of what sexting activities are permissible.
\end{abstract}




\title{
Playing Legislative Catch-Up In 2010 With A Growing, High-TeCh Phenomenon: EVOLVING STATUTORY APPROACHES FOR ADDRESSING TEEN SEXTING
}

\author{
By Clay Calvert, ${ }^{\circ}$ Kara Carnley Murrhee ${ }^{\star} \&$ Jackie Marie Steve ${ }^{\diamond}$ \\ Volume XI - Fall 2010 \\ Copyright $(\mathcal{C}$ Pittsburgh Journal of Technology Law and Policy
}

\section{INTRODUCTION}

"Teen 'sexting" is on the rise."2

So proclaimed a July 2010 USA Today article. $^{3}$ The story explained the results of a survey taken that year which found a whopping forty-three percent of minors aged thirteen to seventeen years reported sexting with their peers. ${ }^{4}$

But it is not just the act of sexting that is capturing media attention today. A quick scan of the headlines from newspapers across the country in 2010 paints a portrait of lawmakers frantically scrambling to play legislative catch-up to address this burgeoning teen phenomenon: ${ }^{5}$

\footnotetext{
- Professor \& Brechner Eminent Scholar in Mass Communication and director of the Marion B. Brechner First Amendment Project at the University of Florida, Gainesville, Fla. B.A., 1987, Communication, Stanford University; J.D. (Order of the Coif), 1991, McGeorge School of Law, University of the Pacific; Ph.D., 1996, Communication, Stanford University. Member, State Bar of California.

- Graduate research associate for the Marion B. Brechner First Amendment Project and student at the Fredric G. Levin College of Law at the University of Florida, Gainesville, Fla. B.A., 2006, Mass Communication, University of Central Florida; M.A., 2010, Mass Communication, University of Florida.

- Undergraduate research associate for the Marion B. Brechner First Amendment Project and public relations student in the College of Journalism and Communications at the University of Florida, Gainesville, Fla.

${ }^{1}$ Sexting generally includes "sending nude photos by text message," and it is "a phenomenon that has infiltrated school systems and involved law enforcement agencies and prosecutors in Georgia and across the nation, and left them unsure yet how to stop and how to punish the behavior." Jeffry Scott, Sexting Stumps State's Schools, Prosecutors, AtLANTA J.-Const., Apr. 22, 2010, at 1A. A group called ConnectSafely notes that sexting "usually refers to teens sharing nude photos via cellphone, but it's happening on other devices and the Web too." ConnectSafely.org, Tips to Prevent Sexting, http://www.connectsafely.org/Safety-Tips/tips-to-prevent-sexting.html (last visited Oct. 25, 2010).

${ }^{2}$ Stephanie Steinberg, 'Sexting' Surges Nationwide, and It's Not Just Teens Doing It, USA ToDAY, July 21, 2010, at 8D (emphasis added).

${ }^{3}$ Id.

${ }^{4} I d$.

${ }^{5}$ A 2009 survey conducted on behalf of the Pew Internet \& American Life Project found that four percent of cell
} 
- Louisiana: "Ban on Juvenile 'Sexting' Approved"6

- Florida: "Sexting' Bill Gets Unanimous Approval by Florida Senate"

- Illinois: "Senate Approves New Rules on Penalties for 'Sexting",8

- Minnesota: "Think 'Sexting' Makes Parents Uncomfortable? Try Legislators"”

- Connecticut: "New State Laws Target Texting, 'Sexting",10

- Pennsylvania: "Committee Approves 'Sexting' Bill”,"11

phone-owning minors surveyed, ranging in age from twelve to seventeen years, said they had sent sexually suggestive nude or nearly nude images of themselves to someone else via text messaging, while fifteen percent said they had received such images of someone they knew via text messaging on their cell phone. Amanda Lenhart, Teens and Sexting: How and Why Minors Are Sending Sexually Suggestive Nude or Nearly Nude Images Via Text Messaging 2 (Pew Internet \& American Life Project, Dec. 15, 2009), available at http://www.pewinternet.org/ /media//Files/Reports/2009/PIP_Teens_and_Sexting.pdf.

Another 2009 survey, this one of minors ranging in age from thirteen to eighteen years that was commissioned by Cox Communications, in partnership with the National Center for Missing and Exploited Children, found that:

About one in five teens have engaged in sexting - sending, receiving, or forwarding sexually suggestive nude or nearly nude photos through text message or email - and over a third know of a friend who has sent or received these kinds of messages. Most sext senders say these messages are most commonly sent to boyfriends/girlfriends because it's asked of them or to have fun. Disturbingly however, about 1 in 10 sext senders say they have sent these messages to people they don't even know.

Cox Communications \& National Center for Missing \& Exploited Children, Teen Online \& Wireless Safety Survey: Cyberbullying, Sexting, and Parental Controls 11 (Cox Communications May 2009), available at http://www.cox.com/takecharge/safe teens 2009/media/2009 teen survey internet and wireless safety.pdf.

${ }^{6}$ Ed Anderson, Ban on Juvenile 'Sexting' Approved; Teens Could Receive a Month in Jail, TIMES-PICAYUNE (New Orleans), May 7, 2010, at A2. See Part I (describing the Louisiana legislation, which became law in 2010, in more detail).

${ }^{7}$ Tonya Alanez, 'Sexting' Bill Gets Unanimous Approval by Florida Senate, Sun SenTINEL (Fort Lauderdale, Fla.), Apr. 30, 2010, available at $\mathrm{http}$ ://www.sun-sentinel.com/news/local/breakingnews/fl-sexting-passes20100429,0,5005059.story.

${ }^{8}$ Timothy Magaw, Senate Approves New Rules on Penalties for 'Sexting,' CHI. DaILy Herald, Apr. 28, 2010, at News 9. See Part I (describing the Illinois legislation, which became law in 2010, in more detail).

${ }^{9}$ Rubén Rosario, Think 'Sexting' Makes Parents Uncomfortable? Try Legislators, St. PAUL PIONEER PresS (Minn.), Apr. 17, 2010, at B1.

${ }^{10}$ Amanda Falcone, New State Laws Target Texting, 'Sexting', HARTFord Courant (Conn.), Sept. 30, 2010, at A12.

${ }^{11}$ Carl Lindquist, Committee Approves 'Sexting' Bill, York DisPatch (Pa.), Mar. 16, 2010. The Pennsylvania measure, House Bill 2189, passed in that state's House of Representatives in June 2010, with its primary sponsor contending that the bill will:

create a tiered system, depending on the specific circumstances in question, with offenses ranging from summary to misdemeanors of the second degree as follows:

Summary charges could apply if a minor knowingly transmits a visual depiction of himself or herself engaging in sexually explicit conduct, and this image is sent to another teen who is known to the sender and a willing recipient.

Second-degree misdemeanor charges could be applied if a minor knowingly transmits or disseminates a visual depiction of himself or herself engaged in sexually explicit conduct; knowingly photographs, videotapes or depicts a minor engaging in sexually explicit conduct; or intentionally views or 


\section{In fact, sixteen different states in 2010, stretching from California to New York,}

considered bills or resolutions designed to address teen sexting. ${ }^{12}$ Why the flurry of legislation?

knowingly possesses a visual depiction of a minor engaged in sexually explicit

conduct.

Press Release, State Representative Seth Grove, Grove's Sexting Legislation Passes House Today (June 29, 2010), available at http://www.repgrove.com/NewsItem.aspx?NewsID=9225.

12 Those states, along with the corresponding bills and their status, are: Arizona (S.B. 1266, 49th Leg., 2d Reg. Sess. (Ariz. 2010) (enacted and described in detail Part I of this article)); California (Assem. Con. Res. 100, Gen. Assem., Reg. Sess. (Cal. 2010) (enacted)); Connecticut (H.B. 5533, 2010 Gen. Assem., Reg. Sess. (Conn. 2010) (enacted and described in detail in Part I of this article)); Florida (S.B. 2560, Reg. Sess. (Fla. 2010) (died in messages in April 2010)); Illinois (H.B. 4583, 96th Gen. Assem., Reg. Sess. (Ill. 2010) (enacted and described in detail in Part I of this article)); Indiana (H.B. 1115, 2d Reg. Sess. (Ind. 2010); S.B. 152, 2d Reg. Sess. (Ind. 2010)); Kentucky (H.B. 57, Reg. Sess. (Ky. 2010); H.B. 143, Reg. Sess. (Ky. 2010)); Louisiana (H.B. 1357, Reg. Sess. (La. 2010) (enacted and described in detail in Part I of this article)); Mississippi (H.B. 643, Reg. Sess. (Miss. 2010) (died in committee)); New Jersey (Assem. B. 1560, 214th Leg. (2010 N.J.) (failed to move out of the Assembly Education Committee, but would have required school districts to annually disseminate information to students and parents or guardians on the dangers of distributing sexually explicit images through electronic means.); Assem. B. 1561, 214th Leg. (2010 N.J.) (failed to move out of the Assembly Judiciary Committee, but would have established an educational program intended as an alternative to prosecution for juveniles charged with a criminal offense for posting sexually suggestive or sexually explicit photographs); Assem. B. 1561, 214th Leg. (2010 N.J.) (failed to move out of the Assembly Consumer Affairs Committee, but would have prohibited retail stores from selling cellular telephone equipment or cellular telephone equipment service contracts unless they provided informational brochures about sexting to customers who purchase such equipment or contracts)); New York (Assem. B. 8622, Reg. Sess. (N.Y. 2010) (amended to its original version in June 2010, and would establish an educational outreach program for text message, email and Internet posting awareness by providing for an ongoing public information and educational campaign about the harm that may arise from adolescents sending, receiving or posting on the Internet messages that may include, but are not limited to, provocative or nude images and photographs of themselves); S.B. 5680, Reg. Sess. (N.Y. 2010) (passed Senate and delivered to Assembly in June 2010, and is the companion bill to Assembly Bill 8622)); Ohio (H.B. 132, 128th Gen. Assem., Reg. Sess. (Ohio 2009-10) (no movement after assigned in April 2009 to the Criminal Justice Committee, and would have provided that "no minor, by use of a telecommunications device, shall recklessly create, receive, exchange, send, or possess a photograph, video, or other material that shows a minor in a state of nudity"); S.B. 103, 128th Gen. Assem., Reg. Sess. (Ohio 2009-10) (no movement after assigned in April 2009 to the Judiciary Criminal Justice Committee, and was the companion bill to Assembly Bill 132); H.B. Sub. 473, 128th Gen. Assem., Reg. Sess. (Ohio 2009-10) (passed in the House in May 2010 by an 86-12 vote, and would provide, in relevant part, that "no minor, by use of a telecommunications device, shall" either "knowingly send, post, exchange, or share a photograph, video, or other material that shows the minor in a state of nudity" or "knowingly send, post, exchange, or share a photograph, video, or other material that shows another minor in a state of nudity")); Oklahoma (H.B. 3321, 52d Leg., 2d Sess. (Okla. 2010) (second reading referred to the Judiciary Committee in February 2010, and would provide reduced criminal penalties (as compared to harsher child pornography penalties) for consensual texting of certain sexual images when "one of the persons is eighteen years of age or older, is currently in a courtship, dating or engagement relationship with the other person and the other person is not under the age of fourteen" or "when both persons are not under the age of fourteen but are less than the age of eighteen”)); Pennsylvania (H.B. 2189, Reg. Sess. (Pa. 2010) (passed in the House on June 29, 2010 by a 163-36 vote, and would create both a second-degree misdemeanor offense and a summary offense for sexting by minors); S.B. 1121, Reg. Sess. (Pa. 2009-10) (referred to the Judiciary Committee in October 2009, and would have prohibited minors under the age of eighteen years from using "a computer or a telecommunications device to knowingly transmit or distribute a photograph" of either himself or "of another minor who is at least 13 years of age, in a state of nudity, to another person who is not more than four years younger or more than four years older than the person transmitting or distributing the photograph or other depiction")); Rhode Island (H. 7778, Gen. Assem., Jan. Sess. (R.I. 2010) (providing that "no minor shall knowingly and voluntarily and without threat or coercion use a computer or telecommunication device to transmit an indecent visual depiction of himself or herself to another 
As The New York Times put it, there is a "growing consensus among lawyers and legislators that the child pornography ${ }^{13}$ laws are too blunt an instrument to deal with an adolescent cyberculture in which all kinds of sexual pictures circulate on sites like MySpace and Facebook."14

Although there may be such a growing consensus among lawyers and legislators, some district attorneys apparently feel quite differently and are using child pornography laws to charge minors who sext. ${ }^{15}$ Indeed, a few "prosecutors are throwing the book at some kids - charging a 13-year-old Ohio girl, for example, with a felony for sending a topless photo of herself to a boyfriend."16

Such Draconian prosecutorial actions, in turn, have mystified many legislators. For instance, New York Assemblyman Kenneth Zebrowski, who sponsored a sexting bill in 2010,

person"); S. 2635, Gen. Assem., Jan. Sess. (R.I. 2010) (providing that "no minor shall knowingly and voluntarily and without threat or coercion use a computer or telecommunication device to transmit an indecent visual depiction of himself or herself to another person"); S. 2871 Sub. A, Gen. Assem., Jan. Sess. (R.I. 2010) (enacted and creating a Senate commission "to study and make recommendations to the Senate relating to the problem of cyberthreats, cyberbullying, bullying, and sexting")); South Carolina (H. 4504, 118th Sess. (S.C. 2010) (making it "unlawful for a person who is at least twelve years of age but less than eighteen years of age to use a telecommunications device to knowingly transmit or distribute to another person who is under the age of eighteen a photograph, text message with a photo attachment, or other transmitted material of any kind depicting himself or another minor in a state of sexual activity or a state of sexually explicit nudity")).

${ }^{13}$ The U.S. Supreme Court has held that the distribution and possession of child pornography is not protected by the First Amendment. See United States v. Williams, 553 U.S. 285, 288 (2008) (writing that "we have held that a statute which proscribes the distribution of all child pornography, even material that does not qualify as obscenity, does not on its face violate the First Amendment" and that "we have held that the government may criminalize the possession of child pornography, even though it may not criminalize the mere possession of obscene material involving adults"); Ashcroft v. Free Speech Coal., 535 U.S. 234, 245-46 (2002) (providing that "as a general principle, the First Amendment bars the government from dictating what we see or read or speak or hear. The freedom of speech has its limits; it does not embrace certain categories of speech, including defamation, incitement, obscenity, and pornography produced with real children") (emphasis added); Osborne v. Ohio, 495 U.S. 103 (1990) (upholding, against a First Amendment challenge, an Ohio law banning the possession of child pornography).

${ }_{14}^{14}$ Tamar Lewin, Rethinking Sex Offender Laws For Youths Showing Off Online, N.Y. TIMES, Mar. 21, 2010, at A1.

${ }^{15}$ See generally Editorial, Friendly Deterrence: The state 'sexting' bill strikes a fair balance, PITT. POST-GAZETTE, July 5, 2010, at B6 (noting that "some prosecutors have been stretching to silly extremes the existing criminal statutes that were designed to address other activities, such as the sexual exploitation of children by adults" and pointing out, to illustrate this assertion, that "in Westmoreland County, six teens involved in sexting were charged with crimes related to child pornography. In Wyoming County, a prosecutor threatened to prosecute 16 teens under the state's pornography statutes").

${ }^{16}$ Aaron Marshall, Ohio House Passes Bill Targeting Juvenile 'Sexting, ' PlaIn DEALER (Cleveland), May 27, 2010, at B2. 
recently remarked that "the sex offender laws were intended to go after people we consider sexual predators, not some kids caught in a youthful indiscretion."17

The following pun thus is very much intended - technology-savvy teens are outstripping child pornography laws. As Linda Terrell, executive director of the Oklahoma Institute for Child Advocacy, put it in July 2010, "this is the next evolution of our society having to deal with technology." 18

The trouble, from a more legal perspective, as attorney Amy Kimpel wrote in a 2010 law journal article, is that child pornography laws were "designed to shield and protect children [but] are turned against them" ${ }^{\prime 19}$ when applied to sexting. Indeed, another recent law journal summarized quite well the problem of applying traditional child pornography laws to teen sexting:

every state prohibits the acts of creating, possessing and distributing images of minors posed in the nude or in a sexually provocative manner. Child pornography involves child abuse viz. exploitation of a minor by an adult - that is typically not present in a teenage sext message. Yet, both fall under child pornography statutes, without regard to this important distinction and thus, minors who engage in sexting can be found criminally liable for child pornography violations. ${ }^{20}$

In response to this dilemma, sexting bills were signed into law in 2010 by the governors of Arizona, Connecticut, Illinois and Louisiana. ${ }^{21}$ These four states' efforts come on top of three

\footnotetext{
${ }^{17}$ Glenn Blain \& Kenneth Lovett, Be Gentle to Teen Sexters: Pols, DAILY NEWS (N.Y.), June 23, 2010 , at 12.

${ }^{18}$ Vallery Brown, District Attorney Says His Only Option to Fight the Trend is to Use Child Pornography Statutes, OKLAHOMAN (Oklahoma City), July 29, 2010, at 11A.

${ }^{19}$ Amy F. Kimpel, Using Laws Designed to Protect as a Weapon: Prosecuting Minors Under Child Pornography Laws, 34 N.Y.U. REV. L. \& Soc. ChANGE 299, 303 (2010).

${ }^{20}$ Shannon Shafron-Perez, Average Teenager Or Sex Offender? Solutions To The Legal Dilemma Caused By

Sexting, 26 J. MARShall J. COMPUTER \& INFO. L. 431, 434 (2009).

${ }^{21}$ See infra Part I (describing the laws in these states in detail).
} 
from 2009, when Utah, ${ }^{22}$ Nebraska ${ }^{23}$ and Vermont ${ }^{24}$ all adopted statutes addressing sexting in some manner. While this article demonstrates that states are taking different approaches to sexting, perhaps the most important aspect of all of the legislation is that it provides "different considerations for minors because they are minors. ${ }^{25}$

The need for statutes that lessen the blow of applying child pornography laws to teens caught sexting is illustrated by cases like the one involving a young Floridian named Philip Alpert. He is now branded, at least until he turns forty-three, as a registered sex offender because, when he was eighteen, he transmitted sexual images of his girlfriend that she, at the age of sixteen, had taken of herself for him. ${ }^{26}$ As Alpert's current attorney, Lawrence Walters, told the lead author of this article, teens:

are not being protected by locking up other teenagers and labeling them sex offenders. Those teens will never lead normal lives, will probably never go to college and will remain unproductive members of society. That result, when combined with the tremendous expense of a typical child pornography prosecution, illustrates the absurdity of pursuing sexting cases as child pornography. ${ }^{27}$

\footnotetext{
${ }^{22}$ See UtAH CODE ANN. § 76-10-1204 (2010) (reducing the penalty for minors of ages sixteen and seventeen years who distribute "pornographic material" to a class A misdemeanor, and reducing the penalty for minors younger than sixteen years of age who engage in this conduct to a class B misdemeanor).

${ }^{23}$ See NeB. REv. STAT. § 28-813.01 (2010) (creating an affirmative defense for the sending of sexual images if: 1) "the defendant was less than nineteen years of age;" 2) the visual depiction of sexually explicit conduct: a) portrays a child fifteen years of age or older; b) was both knowingly and voluntarily generated by the child depicted therein and provided by that same child; and c) contains only one child; 3 ) the defendant did not provide or make available the visual depiction to another person except the child depicted therein who originally sent it to the defendant; and 4) the defendant did not coerce the depicted child to either create or send the visual depiction).

${ }^{24}$ See VT. STAT. ANN. tit. 13, § 2802b (2010) (providing, in relevant part, that "no minor shall knowingly and voluntarily and without threat or coercion use a computer or electronic communication device to transmit an indecent visual depiction of himself or herself to another person," and specifying a series of punishments for minors who violate this provision).

${ }^{25}$ Jim DeBrosse, Lesser Teen Sexting Penalties Sought, Dayton Daily News (Ohio), May 11, 2010, at A1 (quoting Massachusetts Rep. Connie Pillich).

${ }^{26}$ See Clay Calvert, Sexting 101: Teen Bare All on Cell Phones, HustLer, Mar. 2010, at 58, 59 (discussing Alpert's case).

${ }^{27}$ Id. at $59-60$.
} 
While legal scholars and law students are now starting to address the complex mixture of First Amendment, ${ }^{28}$ societal and penal issues surrounding teen sexting, ${ }^{29}$ this article examines the different approaches that legislative bodies are taking today to regulate sexting between and among teenagers (the article does not address sexting either between adults or by an adult to a minor). ${ }^{30}$ The three primary research questions addressed here are:

\section{How are states defining the offense of sexting?}

2. What penalties are imposed on minors for sexting under the new laws, and what, if any, affirmative defenses may minors assert?

\section{What are the apparent strengths and weaknesses of the new laws, including potential situations they may fail to address?}

Part I of this article begins to address all three of these research questions by analyzing the various tacks and tactics taken by the four states that, as of August 25, 2010, had adopted sexting laws that year. ${ }^{31}$ It also examines, when relevant, some notably different approaches taken in 2010 by other states in which sexting bills were proposed but, ultimately, did not become law.

\footnotetext{
${ }^{28}$ The First Amendment to the United States Constitution provides, in pertinent part, that "Congress shall make no law ... abridging the freedom of speech, or of the press." U.S. CONST. amend. I. The Free Speech and Free Press Clauses were incorporated eighty-five years ago through the Fourteenth Amendment Due Process Clause to apply to state and local government entities and officials. See Gitlow v. New York, 268 U.S. 652, 666 (1925).

${ }^{29}$ See, e.g., Catherine Arcabascio, Sexting and Teenagers: OMG R U Going 2 Jail???, 16 RiCH. J.L. \& TECH. 10 (Spring 2010); Clay Calvert, Sex, Cell Phones, Privacy, and the First Amendment: When Children Become Child Pornographers and the Lolita Effect Undermines the Law, 18 COMMLAW CONSPECTUS 1 (2009); John A. Humbach, 'Sexting' and the First Amendment, 37 Hastings Const. L.Q. 433 (Spring 2010); W. Jesse Weins \& Todd C. Hiestand, Sexting, Statutes, and Saved by the Bell: Introducing a Lesser Juvenile Charge with an "Aggravating Factors" Framework, 77 TENN. L. REV. 1 (Fall 2009); Robert H. Wood, The Failure of Sexting Criminalization: A Plea for the Exercise of Prosecutorial Restraint, 16 Mich. Telecomm. TeCH. L. ReV. 151 (Fall 2009).

${ }^{30}$ Sadly, some adults do sext with minors, as illustrated by two 2010 cases. See Matt Gunderson, Nude Photos: Teacher Apologizes, UNION LEADER (Manchester, N.H.), July 27, 2010, at 8 (describing how a 41-year-old former high school teacher apologized for emailing nude photos of herself to a 15-year-old boy, and noting the boy's assertion that he had "exchanged numerous text messages of a sexual nature with her"); Erin Sullivan, Sexting Charges Lead to Firing, St. Petersburg Times (Fla.)., Apr. 9, 2010, at Pasco Times 1 (describing the arrest of a 24-year-old man who was accused of sending sexual text messages to a 14-year-old member of his church). The topic of sexting between adults drew headlines in October 2010 relating to veteran National Football League quarterback "Brett Favre's alleged sexting to a female New York Jets employee when both worked for that team." Michael Hiestand, Talkers Side with NFL on Hard Hits, USA TODAY, Oct. 25, 2010, at 3C.

${ }^{31}$ See infra notes $35-155$ and accompanying text.
} 
For purposes of brevity, Part I focuses on four facets of the new laws, namely their: 1) definitions of sexting; 2) age variations, in terms of the perpetrators targeted by the offense of sexting; 3) remedies and punishments imposed; and 4) defenses and mitigating factors articulated in statutory language that may lessen or otherwise affect punishment for the crime of sexting.

Part II then constructs a realistic, hypothetical teen-sexting scenario and, in turn, applies the new laws adopted by Arizona, Connecticut, Illinois and Louisiana to the facts of that hypothetical situation. ${ }^{32}$ The application of these statutes to a simulated sexting scenario helps to illustrate some of their seeming strengths and weaknesses and, in the process, to answer the third research question posed above. Part II makes it clear that the four laws are far more different in their application than they seem when initially reviewed on paper.

Finally, Part III suggests this emerging area of the law will continue to test the edges of both the fairness of criminal penalties and the First Amendment freedom of speech. ${ }^{33}$ It also raises a related issue for scholars to address in the near future, namely the phenomenon of "sextortion," ${ }^{34}$ particularly when engaged in by minors over sexted images.

\section{I. \\ The 2010 Legislative Landscape Of SeXting LAws: Commonalities And Differences Among State APProAChes}

Sections A, B, C and D of this part of the article analyze the sexting laws adopted by the states of Arizona, Connecticut, Illinois and Louisiana in 2010. In particular, Section A addresses how each of the four states defines the offense of sexting, including the core elements that comprise the offense. Section B then examines age-based variations in terms of the perpetrators

\footnotetext{
${ }^{32}$ See infra notes $156-200$ and accompanying text.

${ }^{33}$ See infra notes $201-215$ and accompanying text.

${ }^{34}$ See infra notes $201-207$ and accompanying text.
} 
targeted by each state. Next, Section $\mathrm{C}$ analyzes the punishments and penalties meted out under the four new laws, and finally Section D examines possible defenses and mitigating factors. Bills from other states that were proposed in 2010 but failed to become law are described in Section E only to the extent they suggest markedly different approaches.

\section{A. Defining Sexting: Essential Elements of the Offense}

The threshold issue is the manner in which states are defining the offense of sexting. Explicating the crime of sexting is not easy because, unlike another category of sexually explicit expression - namely, obscenity ${ }^{35}$ - sexting lacks an established test or definition created by the United States Supreme Court that can be mirrored by state statutes. As noted in a June 2010 report prepared for the National Institute of Justice, ${ }^{36}$ "there is no legal definition of sexting, making it a legal gray area."37

This section reveals that, in explicating the offense of sexting, all four of the 2010 laws focus on a trio of critical elements that must be present, in addition to the obligatory mens rea or mental requirement, ${ }^{38}$ specifically:

\footnotetext{
${ }^{35}$ Obscenity falls outside the First Amendment's protection of free speech. See Roth v. United States, 354 U.S. 476, 485 (1957) (writing that "obscenity is not within the area of constitutionally protected speech or press"). In Miller v. California, 413 U.S. 15, 24 (1973), the nation's high court held that when determining whether material is obscene, jurors and judges must consider: 1) whether the average person, applying contemporary community standards, would find that the work, taken as a whole, appeals to a prurient interest; 2) whether it depicts or describes, in a patently offensive way, sexual conduct specifically defined by the applicable state law; and 3) whether, taken as a whole, it lacks serious literary, artistic, political or scientific value.

${ }^{36}$ This organization "is the research, development and evaluation agency of the U.S. Department of Justice." About NIJ, National Institute of Justice, http://www.ojp.usdoj.gov/nij/about/welcome.htm (last visited Oct. 25, 2010).

${ }^{37}$ Miranda Jolicoeur \& Edwin Zedlewski, Much Ado About Sexting at 4 (June 2010) (unpublished, National Institute of Justice), available at http://ncjrs.gov/pdffiles1/nij/230795.pdf.

${ }^{38}$ See Clark v. Arizona, 548 U.S. 735, 742 (2006) ("[T] he mental element of the crime charged" is "known in legal shorthand as the mens rea, or guilty mind."). See generally Martin R. Gardner, The Mens Rea Enigma: Observations on the Role of Motive in the Criminal Law Past and Present, 1993 UTAH L. ReV. 635 (1993) (describing both the history of the mens rea element and the problems with its meaning and application).
} 
- mode of transmission: requiring electronic communication technology;

- content of the image: requiring sexually explicit images of minors; and

- age of the perpetrator: targeting minors as the offenders.

Expressed even more simply, there is a triangulation among the elements of technology, content and age that helps to define sexting. The sexting laws adopted in 2010 by four states evidence the growing legislative consensus that these three variables constitute essential elements for the offense of sexting. As the article later demonstrates, however, there are substantial differences among the states on how these elements are defined.

In addition to this trio of requisite elements, states seem to be targeting for punishment under sexting laws:

- the sender/trasmittor of the image; and/or

- the recipient/possessor of the image.

Where the states differ, however, is on the question of which particular transmitters/senders they target - do they target either what the authors this article call selfsexters (those minors who take sexually explicit photographs of themselves and then send them to others) or what the authors dub as downstream-sexters (those minors who receive photographs of other minors and then further transmit or forward them to other, third-party minors)? The states themselves do not use the terms self-sexters or downstream-sexters; the authors coin them here for purposes of ease in understanding the variations among the laws when it comes to the type of senders they target.

The four sexting statutes adopted in 2010 are described separately below, in alphabetical order by the name of the state that enacted them. 


\section{Arizona}

In May 2010, Arizona Governor Janice Brewer signed into law ${ }^{39}$ Senate Bill $1266{ }^{40}$ The law, which does not use the term "sexting," instead creates an offense for the "unlawful use of an electronic communication device by a minor."41

It provides, in relevant part, that "it is unlawful for a juvenile to intentionally or knowingly use an electronic communication device to transmit or display a visual depiction of a minor that depicts explicit sexual material"42 and that "it is unlawful for a juvenile to intentionally or knowingly possess a visual depiction of a minor that depicts explicit sexual material and that was transmitted to the juvenile through the use of an electronic communication device."43 The former provision targets the transmission of sexted images, while the latter targets their possession.

As illustrated by the italicized portions of both of the above-quoted sections of the statute, the offense of sexting in Arizona relates not only to the nature of the content of the images (they must depict a minor in an explicit sexual manner ${ }^{44}$ ), but also to their mode of distribution (they must be distributed through an electronic communication device) and to the age of the perpetrator of the offense (the offense targets juveniles who transmit, display or possess the content).

\footnotetext{
${ }^{39}$ See Letter from Janice K. Brewer, Arizona Governor, to Ken Bennett, Arizona Secretary of State, at 2 (May 7 , 2010) available at http://azgovernor.gov/dms/upload/PR_051010_TransEnacts.pdf (noting the signing of Senate Bill 1266).

${ }^{40}$ S.B. 1266, 49th Leg., 2d Reg. Sess. (Ariz. 2010) (enacted).

${ }^{41}$ ARIZ. ReV. StAT. ANN. § 8-309 (2010).

42 ARIZ. REV. STAT. ANN. § 8-309(A) (2010) (emphasis added).

${ }^{43}$ ARIZ. REV. STAT. ANN. § 8-309(B) (2010) (emphasis added).

${ }^{44}$ The new law defines such content as "material that depicts human genitalia or that depicts nudity, sexual activity, sexual conduct, sexual excitement or sadomasochistic abuse as defined in section 13-3501." ARIZ. REV. STAT. ANN. $\S 8-309(\mathrm{G})(2)(2010)$. In turn, the referenced section, which already was law, provides more complete and precise definitions of nudity, sexual activity, sexual conduct, sexual excitement or sadomasochistic abuse. See ARIZ. REV. STAT. ANN. § 13-3501 (2010) (defining, for instance, nudity as the display of either "human male or female genitals, pubic area or buttocks with less than a full opaque covering, or the showing of the female breast with less than a fully opaque covering of any portion thereof below the top of the nipple, or the depiction of covered male genitals in a discernibly turgid state").
} 
Importantly, the Arizona law targets both the intentional or knowing transmission/display of sexted images, as well as the mere knowing possession of them. ${ }^{45}$ In other words, the state's lawmakers chose to go after not only juveniles who knowingly send sexually explicit images, but also those who knowingly keep them after receipt. But as Section D of this Part of the article emphasizes, the Arizona legislature carefully crafted an exception from prosecution for those juvenile-possessors of sexted images who did not solicit them and who took efforts either to destroy them or to report them to certain enumerated authority figures. ${ }^{46}$

Finally, it is important to emphasize that Arizona's statute appears to target for prosecution individuals whom the authors of this article term self-sexters (those minors who take sexually explicit photographs of themselves and send them to others), as well as what the authors dub as downstream-sexters (those minors who receive photographs of other minors and then further transmit or forward them to other minors). In particular, the Arizona law focuses on juveniles who transmit "a visual depiction of a minor that depicts explicit sexual material." $" 47$ Rather than use possible terms such as "a visual depiction of himself" or "a visual depiction of another minor," the Arizona law employs the neutral or generic term "a minor."

Put differently, the law fails to denote whether the word "minor" is directed only at those minors who transmit images of themselves (self-sexters) or also at those who transmit images of others (downstream-sexters). By failing to spell out or specify who must be the subject of the visual depiction, the statute seemingly allows both self- and downstream-sexters to be targeted for prosecution.

\footnotetext{
${ }^{45}$ Under Arizona law, the term "'knowingly' means, with respect to conduct or to a circumstance described by a statute defining an offense, that a person is aware or believes that the person's conduct is of that nature or that the circumstance exists. It does not require any knowledge of the unlawfulness of the act or omission." ARIZ. REV. STAT. ANN. § 13-105 (10)(b) (2010). The term "intentionally," in contrast, "means, with respect to a result or to conduct described by a statute defining an offense, that a person's objective is to cause that result or to engage in that conduct." ARIZ. ReV. STAT. ANN. § 13-105 (10) (a) (2010).

${ }^{46}$ Infra Part I, Section D, Subsection 1.

${ }^{47}$ ARIZ. ReV. StAT. ANN. § 8-309(A) (2010) (emphasis added).
} 


\section{Connecticut}

In June 2010, Connecticut Governor M. Jodi Rell signed into law House Bill 5533. ${ }^{48}$

Taking effect in October 2010, the new measure provides, in relevant part, that:

No person who is thirteen years of age or older but under sixteen years of age may knowingly and voluntarily transmit by means of an electronic communication device $e^{49}$ a visual depiction of child pornography ${ }^{50}$ in which such person is the subject of such visual depiction to another person who is thirteen years of age or older but under eighteen years of age. ${ }^{51}$

In addition to targeting the knowing and voluntary transmission of such images, the

Connecticut statute aims at their knowing possession:

No person who is thirteen years of age or older but under eighteen years of age may knowingly possess any visual depiction of child pornography that the subject of such visual depiction knowingly and voluntarily transmitted by means of an electronic communication device to such person and in which the subject of such visual depiction is a person thirteen years of age or older but under sixteen years of age. ${ }^{52}$

Under this law, the offense of sexting relates not only to the nature of the content of the images (they must depict child pornography), but also to the mode of their distribution (the images must be transmitted via an electronic communication device) and to the age of the

\footnotetext{
${ }^{48}$ An Act Concerning Sexting, H.B. 5533, 2010 Gen. Assem., Reg. Sess. (Conn. 2010) (enacted), available at http://www.cga.ct.gov/2010/ACT/PA/2010PA-00191-R00HB-05533-PA.htm.

${ }^{49}$ The bill defines an electronic communication device as "any electronic device that is capable of transmitting a visual depiction, including a computer, computer network and computer system, as those terms are defined in section $53 \mathrm{a}-250$ of the general statutes, and a cellular or wireless telephone." Id.

${ }^{50}$ Connecticut law defines child pornography as: any visual depiction including any photograph, film, videotape, picture or computer-generated image or picture, whether made or produced by electronic, mechanical or other means, of sexually explicit conduct, where the production of such visual depiction involves the use of a person under sixteen years of age engaging in sexually explicit conduct, provided whether the subject of a visual depiction was a person under sixteen years of age at the time the visual depiction was created is a question to be decided by the trier of fact.

CONN. GEN. STAT. § 53a-193 (2010).

${ }^{51}$ An Act Concerning Sexting, H.B. 5533, § 2, 2010 Gen. Assem., Reg. Sess. (Conn. 2010) (enacted), available at http:/www.cga.ct.gov/2010/ACT/PA/2010PA-00191-R00HB-05533-PA.htm (emphasis added).

${ }^{52} I d$. (emphasis added).
} 
perpetrators (sender-perpetrators must be thirteen, fourteen or fifteen years old, while recipientpossessor- perpetrators must be thirteen, fourteen, fifteen, sixteen or seventeen years of age). As with Arizona's law, the new Connecticut measure thus addresses both the knowing transmission and knowing possession of sexted images.

Furthermore, on the issue of transmission, Connecticut's law targets only self-sexters, rather than both self-sexters and downstream-sexters. In particular, it clearly targets self-sexters when it provides that "no person who is thirteen years of age or older but under sixteen years of age may knowingly and voluntarily transmit by means of an electronic communication device a visual depiction of child pornography in which such person is the subject of such visual depiction." ${ }^{53}$ In brief, the term "no person" refers directly to the term "such person" as it relates to the subject of the visual depiction.

There is no similar provision, however, targeting the recipients of those images who may later forward them to others. Specifically, the other part of the Connecticut law targets minors who "may knowingly possess any visual depiction of child pornography that the subject of such visual depiction knowingly and voluntarily transmitted." 54 This language only targets possession, not further transmission, leading to the result that Connecticut targets only selfsexters.

\section{Illinois}

Illinois House Bill $4583,{ }^{55}$ which was signed into law by Governor Pat Quinn in July $2010^{56}$ and takes effect on January 1, 2011, provides that "a minor shall not distribute or

\footnotetext{
${ }^{53} I d$. (emphasis added).

${ }^{54} \mathrm{Id}$.

${ }^{55}$ H.B. 4583, 96th Gen. Assem., Reg. Sess. (Ill. 2010) (enacted), available at http://www.ilga.gov/legislation/publicacts/96/PDF/096-1087.pdf.

${ }^{56}$ See Press Release, Illinois Governor's Office, Governor Quinn Signs Legislation to Improve Public Safety Protects Minors from “Sexting," Internet Exploitation; Toughens Sex Offender Registry Requirements (July 18, 2010), available at http://www.illinois.gov/PressReleases/ShowPressRelease.cfm?SubjectID=3\&RecNum=8650
} 
disseminate an indecent visual depiction of another minor through the use of a computer or electronic communication device." depiction or portrayal in any pose, posture, or setting involving a lewd exhibition of the unclothed or transparently clothed genitals, pubic area, buttocks, or, if such person is female, a fully or partially, developed breast of the person."58 An electronic dissemination, in turn, refers to "an electronic device, including but not limited to a wireless telephone, personal digital assistant, or a portable or mobile computer, that is capable of transmitting images or pictures."59 A minor is "a person under 18 years of age." 60

As with the 2010 sexting laws adopted in Arizona and Connecticut, the Illinois statute includes the three core elements on which legislative bodies are triangulating to define the offense of sexting: 1) content (an indecent visual communication); 2) mode of transmission (a computer or electronic communication device); and 3) age of the perpetrator (a minor).

The Illinois law, however, differs significantly from those of Arizona and Connecticut because it targets only minors who "distribute or disseminate" 61 sexted images, not those who possess them. Additionally, it targets only minors who "distribute or disseminate an indecent visual depiction of another minor." ${ }^{62}$ In other words, it omits from its application what the authors of this article dub as self-sexters - individuals who take photographs of themselves and send them to others. It only targets only what the authors call downstream-sexters - minors who

\footnotetext{
(noting that "Governor Pat Quinn today signed a package of legislation that will further enhance public safety. The new laws protect minors from sexually explicit images through "sexting," and asserting that the new sexting law "offer[s] a standalone remedy for law enforcement and prosecutors that does not put the minor in the same category as child pornographers and require the minor to register as a sex offender").

${ }^{57}$ An Act Concerning Criminal Law, Act of July 19, 2010, Pub. Act. No. 096-1087, § 3-40(b), Ill. Laws (2010) (Reg. Sess.), available at http://www.ilga.gov/legislation/publicacts/96/PDF/096-1087.pdf.

${ }^{58} I d$.

${ }^{59} I d$.

${ }^{60} I d$.

${ }^{61} I d$.

${ }^{62} I d$. (emphasis added).
} 
forward images of other minors, not images of themselves.

\section{Louisiana}

In June 2010, after an overwhelming House vote of 89-0 and a similarly unanimous Senate vote of 37-0, Louisiana legislators sent to Republican Governor Bobby Jindal a revamped House Bill $1357^{63}$ that creates the crime of sexting. ${ }^{64}$ Jindal signed the measure into law in July 2010, and it took effect on August 15 that year. ${ }^{65}$

The new law targets both the transmission and possession of sexted images by teens in Louisiana, as it provides that "no person under the age of seventeen years shall knowingly and voluntarily use a computer or telecommunication device ${ }^{66}$ to transmit an indecent visual depiction ${ }^{67}$ of himself to another person" ${ }^{98}$ and that "no person under the age of seventeen years shall knowingly possess or transmit an indecent visual depiction that was transmitted by another under the age of seventeen years." ${ }^{\circ 9}$

As with the laws in Arizona, Connecticut and Illinois, the Louisiana measure centers on the coalescence of three elements (in addition to the "knowingly" mens rea element): the content of the image (it must be an indecent depiction); the mode of transmission (it must be

\footnotetext{
${ }^{63}$ H.B. 1357, Reg. Sess. (La. 2010) (enacted).

${ }^{64}$ Ed Anderson, Legislators Toughen Ban on Historic-District Graffiti; Cyberbullying, Sexting to be Illegal, TIMESPICAYUNE (New Orleans), June 22, 2010, at A3.

${ }^{65}$ Ed Anderson, Jindal Signs Cyberbully, Sexting Bills into Law; Measures Will Take Effect Aug. 15, TIMESPICAYUNE (New Orleans), July 9, 2010, at A2.

${ }^{66}$ The new statute defines a telecommunications device as "an analog or digital electronic device which processes data, telephonic, video, or sound transmission as part of any system involved in the sending or receiving of voice, sound, data, or video transmissions." LA. REV. STAT. ANN. § 14:81.1.1(B)(3) (2010).

${ }^{67}$ The new statute defines an indecent visual depiction as "any photograph, videotape, film, or other reproduction of a person under the age of seventeen years engaging in sexually explicit conduct, and includes data stored on any computer, telecommunication device, or other electronic storage media which is capable of conversion into a visual image.” LA. REV. STAT. ANN. § 14:81.1.1(B)(1) (2010). The term "sexually explicit conduct" as use therein is defined as "masturbation or lewd exhibition of the genitals, pubic hair, anus, vulva, or female breast nipples of a person under the age of seventeen years.” LA. REV. STAT. ANN. § 14:81.1.1(B)(2) (2010).

${ }^{68}$ LA. REV. STAT. ANN. $§ 14: 81.1 .1(\mathrm{~A})(1)(2010)$.

${ }^{69}$ LA. REV. STAT. ANN. § 14:81.1.1(A)(2) (2010).
} 
transmitted by a computer or telecommunications device); and the age of the perpetrator (he or she must be under the age of seventeen). And like Arizona and Connecticut, Louisiana's sexting statute targets both the transmission and possession of images.

Louisiana's statute is unique among the four states, however, when it comes to content because it specifically singles out by its terms a minor who transmits "an indecent visual depiction of himself, ${ }^{, 70}$ as well as downstream-sexters - individuals who forward such images of others - when it provides that "no person under the age of seventeen years shall knowingly possess or transmit an indecent visual depiction that was transmitted by another under the age of seventeen years." ${ }^{, 71}$ In contrast, Illinois' law targets only downstream-sexters, when it provides that "a minor shall not distribute or disseminate an indecent visual depiction of another minor through the use of a computer or electronic communication device., ${ }^{, 2}$ Conversely, Connecticut only targets self-sexters. As explained earlier, Arizona's use of the term "a minor",3 when it comes to those who transmit sexted images is ambiguous; thus Connecticut seems to target both self-sexters and downstream-sexters, but, unlike Louisiana, does not make this clear.

\section{Summary}

The four states that adopted sexting statutes in 2010 all defined the underlying crime as an offense that is:

- technology-specific,

- content-specific, and

- age-specific.

\footnotetext{
${ }^{70}$ LA. REV. STAT. ANN. § 14:81.1.1(A)(1) (2010) (emphasis added).

${ }^{71}$ LA. REV. STAT. ANN. § 14:81.1.1(A)(2) (2010) (emphasis added).

${ }^{72}$ An Act Concerning Criminal Law, Act of July 19, 2010, Pub. Act. No. 096-1087, § 3-40(b), Ill. Laws (2010)

(Reg. Sess.), available at http://www.ilga.gov/legislation/publicacts/96/PDF/096-1087.pdf (emphasis added).

${ }^{73}$ Supra note 47 and accompanying text.
} 
There are, however, slight variations in the terms used by each state to describe each of these three core elements. For instance, when it comes to the nature of the specific content that can land minors in trouble, Arizona uses the term "explicit sexual material" (and references an already-on-the-books statute to clarify the meaning of the words used therein) $;{ }^{74}$ Connecticut adopts the term "child pornography" (also already defined under that state's penal statutes), ${ }^{75}$ Illinois uses the phrase "indecent visual communication"; ${ }^{76}$ and Louisiana employs the term "indecent visual depiction.,"77 A close examination of the precise definitions of these terms, ${ }^{78}$ however, illustrates that these variations are semantical rather than substantive distinctions.

One major difference in defining the offense of sexting is found in the Illinois law, which targets only the distribution and dissemination of sexted images. The other three states, in contrast, target both the transmission (the distribution and dissemination, as the Illinois law terms it) and possession of such images. The following table helps to elucidate this point, summarizing the targets for the offense of sexting in Arizona, Connecticut, Illinois and Louisiana.

\footnotetext{
${ }^{74}$ The new law defines such content as "material that depicts human genitalia or that depicts nudity, sexual activity, sexual conduct, sexual excitement or sadomasochistic abuse as defined in section 13-3501." ARIZ. REV. STAT. ANN. $\S 8-309(\mathrm{G})(2)(2010)$.

${ }^{75}$ CONN. GEN. STAT. § 53a-193(13) (2010) (defining child pornography as "any visual depiction ... of sexually explicit conduct, where the production of such visual depiction involves the use of a person under sixteen years of age engaging in sexually explicit conduct"). Connecticut law, in turn, defines sexually explicit conduct as: actual or simulated (A) sexual intercourse, including genital-genital, oralgenital, anal-genital or oral-anal physical contact, whether between persons of the same or opposite sex, or with an artificial genital, (B) bestiality, (C) masturbation, (D) sadistic or masochistic abuse, or (E) lascivious exhibition of the genitals or pubic area of any person.

CONN. GEN. STAT. § 53a-193(14) (2010).

${ }^{76}$ It defines an indecent visual communication as "a depiction or portrayal in any pose, posture, or setting involving a lewd exhibition of the unclothed or transparently clothed genitals, pubic area, buttocks, or, if such person is female, a fully or partially, developed breast of the person." An Act Concerning Criminal Law, Act of July 19, 2010, Pub. Act. No. 096-1087, § 3-40(a), Ill. Laws (2010) (Reg. Sess.), available at http://www.ilga.gov/legislation/publicacts/96/PDF/096-1087.pdf.

${ }_{77}$ The new statute defines an indecent visual depiction as "any photograph, videotape, film, or other reproduction of a person under the age of seventeen years engaging in sexually explicit conduct, and includes data stored on any computer, telecommunication device, or other electronic storage media which is capable of conversion into a visual image." LA. REV. STAT. ANN. § 14:81.1.1(B)(1) (2010). The term "sexually explicit conduct" as use therein is defined as "masturbation or lewd exhibition of the genitals, pubic hair, anus, vulva, or female breast nipples of a person under the age of seventeen years." LA. REV. STAT. ANN. § 14:81.1.1(B)(2) (2010).

${ }^{78}$ See supra notes 44, 50, 58 and 67 and accompanying text (setting forth the statutory definitions of these terms).
} 
Table 1. Who Are the Perpetrators Targeted for Sexting:

Image Senders or Image Possessors?

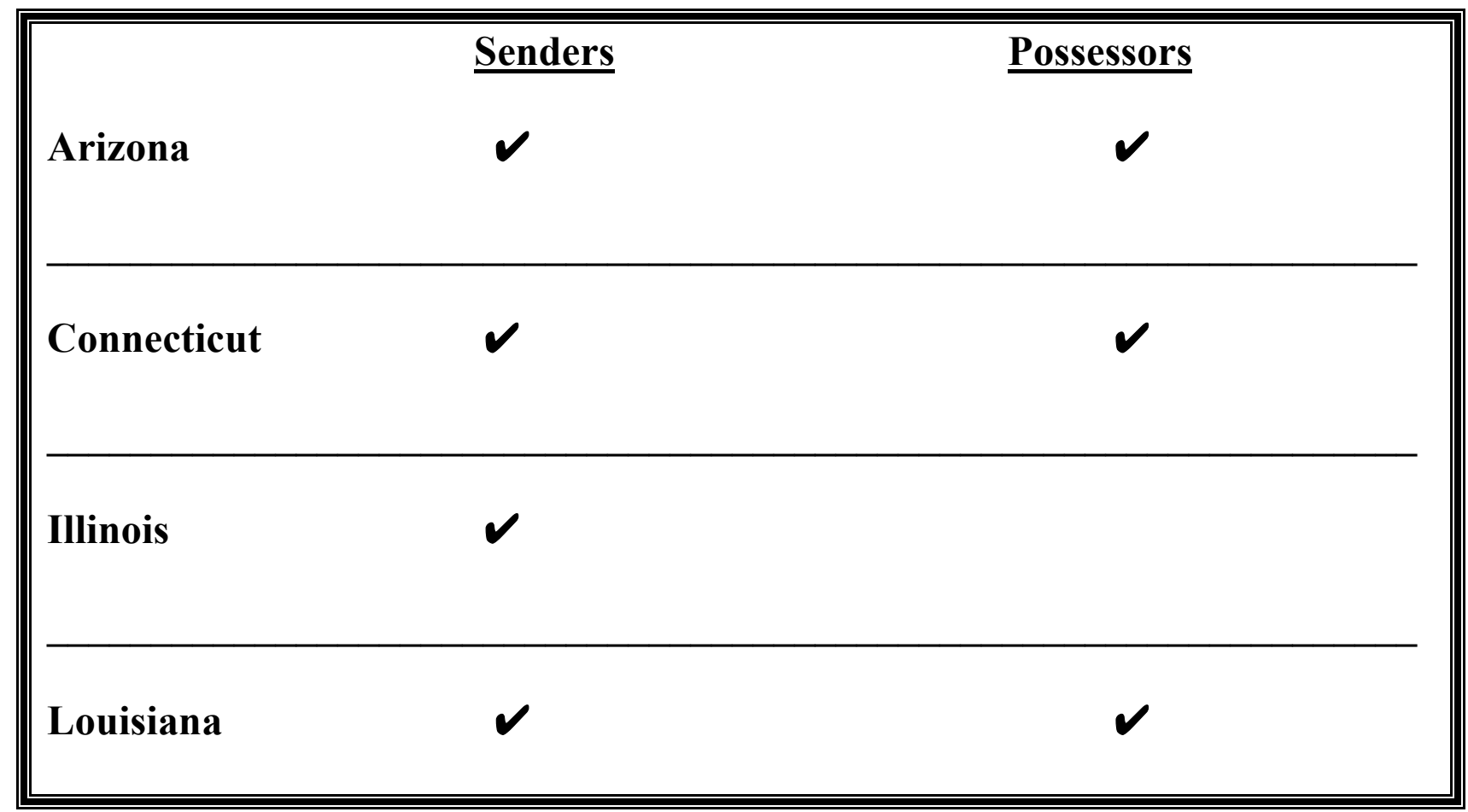

Another critical difference relates to whether the laws target self-sexters, downstreamsexters or both when it comes to liability for the transmission of sexted images. Arizona and Louisiana target both types of senders - self-sexters and downstream-sexters - while Connecticut's law singles out self-sexters for prosecution and, conversely, Illinois targets only downstream-sexters. The following table helps to make this clear. 
Table 2. Which Senders of Sexted Images Are Targeted:

Self-Sexters or Downstream-Sexters?

\begin{tabular}{|c|c|c|}
\hline Arizona & $\frac{\text { Self-Sexters }}{\checkmark}$ & $\begin{array}{c}\text { Downstream-Sexters } \\
\checkmark\end{array}$ \\
\hline Connecticut & $v$ & \\
\hline Illinois & & $\nu$ \\
\hline Louisiana & $\checkmark$ & $\nu$ \\
\hline
\end{tabular}

Differences in the age of perpetrators targeted for prosecution across the four laws are discussed below in Section B.

\section{B. Ages of Perpetrators Targeted by Sexting Statutes}

The states that adopted sexting laws in 2010 took two very different approaches in terms of classifying perpetrators by age. Those approaches are:

- a one-size-fits-all-ages definition of perpetrators; and

- an age-makes-a-difference definition of perpetrators.

These approaches, as well as a critique of them, are set forth below on a state-by-state basis. 


\section{Arizona: Anyone Under Eighteen Years of Age Is a Perpetrator}

Arizona uses the term "juvenile" 79 to describe sexting perpetrators under the statute it adopted in 2010. Although the bill fails to define the term "juvenile," other relevant Arizona statutes define it as a person who is under eighteen years of age. ${ }^{80}$ This interpretation is confirmed because Arizona defines the term "adult" as "a person who has attained the age of eighteen years."

Thus, Arizona has adopted what might be dubbed a one-size-fits-all approach when it comes to minors who sext. In other words, a seventeen-year-old boy is treated exactly the same under the statute as a seven-year-old boy who sexts, despite the fact that one is ten years older than the other. To put it bluntly, a juvenile is a juvenile, as long as the person is under eighteen years of age. The Arizona statute does not include any mitigating factors that lessen the offense based upon the age of the offender.

The authors query whether it makes sense to treat all juveniles in similar fashion under Arizona's sexting statute. A seventeen-year-old boy who sexts is just one year away from being able to vote, but a seven-year-old boy who sexts likely has not yet even reached puberty. The two would seem to be at different ages of cognitive development in terms of their ability to appreciate or understand the potential ramifications of their conduct.

In Arizona, it is now left to prosecutorial discretion whether to bring charges under the new law against younger juveniles who sext or treat them like older juveniles. A meeting with an assistant district attorney may be lesson enough for a twelve-year-old boy that sexting is wrong.

\footnotetext{
${ }^{79}$ The law provides that "it is unlawful for a juvenile to intentionally or knowingly use an electronic communication device to transmit or display a visual depiction of a minor that depicts explicit sexual material." ARIZ. REV. STAT. ANN. § 8-309 (2010) (emphasis added).

${ }^{80}$ See ARIZ. REV. STAT. ANN. § 8-201(6) (2010) (providing that “'juvenile' means an individual who is under the age of eighteen years"); ARIZ. REV. STAT. ANN. § 8-291 (2010) (providing, in the context of juvenile competency hearings, that " "juvenile' means a person who is under eighteen years of age at the time the issue of competency is raised")

${ }^{81}$ ARIZ. Rev. STAT. ANN. § 1-215 (2010).
} 
On the other hand, the prosecutor now has a statutory weapon under which to charge that boy if taking such a measure provides a better resolution to the matter.

\section{Connecticut: A Nuanced Perspective-All Minors Are Not Alike}

Of the four states that adopted sexting laws in 2010, Connecticut took the most nuanced approach in defining the perpetrators targeted by its sexting statute. In particular, when it comes to minors who knowingly possess sexted images that are deemed as child pornography under state law, the perpetrators targeted are individuals who are "thirteen years of age or older but under eighteen years of age." ${ }^{\prime 82}$ This means that minors who are twelve years of age or younger are not subject to prosecution under the new Connecticut statute for possessing sexted images. Conceivably, minors twelve years of age or younger are subject to Connecticut's statute regulating the possession of child pornography, ${ }^{83}$ but such a prosecution would be illogical in contrast to the lesser offense of sexting for a thirteen-year-old minor. This is a starkly different approach to the issue of perpetrator age from the Arizona law, described above, ${ }^{84}$ that treats a twelve-year-old possessor in the same fashion as a seventeen-year-old possessor.

Similar to the issue of possession, when it comes to the knowing transmission of sexted images, Connecticut law takes a nuanced approach, but one that is even more limited or cabined in terms of the age of the perpetrators targeted. In particular, it provides that "no person who is thirteen years of age or older but under sixteen years of age may knowingly and voluntarily transmit by means of an electronic communication device a visual depiction of child

\footnotetext{
${ }^{82}$ An Act Concerning Sexting, Pub. Act. No. 10-191, § 1, 2010 Conn. Acts (2010) (Reg. Sess.), available at http://www.cga.ct.gov/2010/ACT/PA/2010PA-00191-R00HB-05533-PA.htm.

${ }^{83}$ See CONN. GEN. STAT. § 53a-196d(a) (2010) (providing that "a person is guilty of possessing child pornography in the first degree when such person knowingly possesses fifty or more visual depictions of child pornography").

${ }^{84}$ Supra Part I, Section B, Subsection 1.
} 
pornography. ${ }^{\Perp 85}$ This is a very narrow, three-year window for perpetrator age, sweeping up only those minors who are thirteen, fourteen or fifteen years of age.

What this three-year window of liability under the new sexting statute does is create a three-tiered level of potential prosecution for minors who transmit images of child pornography:

- Older Minors: Minors sixteen- and seventeen-years-old in Connecticut are omitted from the terms of the new sexting statute when they knowingly and voluntarily transmit child pornography. Thus, they are treated akin to adults and, in turn, are subject to prosecution under Connecticut's child pornography statute when they transmit images of child pornography. ${ }^{86}$

- Minors Ages Thirteen- Through Fifteen-Years-Old: Minors who are thirteen, fourteen and fifteen years of age in Connecticut are subject to prosecution under the terms of the new sexting statute when they knowingly and voluntarily transmit child pornography. In brief, age thirteen is the floor for eligibility of the offense of sexting, while age fifteen is the ceiling.

- Minors Under Thirteen-Years-Old: Minors under the age of thirteen who knowingly and voluntarily transmit child pornography are too young for prosecution under the terms of Connecticut's new sexting statute. While they technically are subject to generally applicable child pornography laws, it would seem that the fact the legislature did not target them for the offense of transmitting sexted images implies an intent that they should not be subject to prosecution.

Of the four states that adopted sexting legislation in 2010 , Connecticut is the only one to adopt such a tripartite approach when it comes to the electronic transmission of sexually explicit

\footnotetext{
${ }^{85}$ An Act Concerning Sexting, Pub. Act. No. 10-191, § 2, 2010 Conn. Acts (2010) (Reg. Sess.), available at http://www.cga.ct.gov/2010/ACT/PA/2010PA-00191-R00HB-05533-PA.htm (emphasis added).

${ }^{86}$ See CONN. GEN. STAT. $§ 53 a-196 c$ (2010) (providing that a "person is guilty of importing child pornography when, with intent to promote child pornography, such person knowingly imports or causes to be imported into the state three or more visual depictions of child pornography of known content and character").
} 
images by minors. It should be lauded for creating and adopting floors and ceilings of eligibility for the offense of sexting.

\section{Illinois: Anyone Under Eighteen Years of Age Is a Perpetrator}

The approach to age taken by Illinois mirrors that of Arizona. In particular, the Illinois measure defines a minor as "a person under 18 years of age. ${ }^{, 87}$ Illinois also adopts a one-sizefits-all approach to sexting by minors, rather than the tripartite approach of Connecticut for the transmission of sexted images, by simply stating that minors "shall not distribute or disseminate an indecent visual depiction of another minor through the use of a computer or electronic communication device. ${ }^{, 88}$ In other words, all minors, no matter what age, are treated alike under the terms of the Illinois legislation.

\section{Louisiana: Anyone Under Seventeen Years of Age}

While both Arizona and Illinois define minors in their new sexting laws as individuals under the age of eighteen, Louisiana lowers the age slightly by providing that "no person under the age of seventeen years shall knowingly and voluntarily use a computer or telecommunication device to transmit an indecent visual depiction of himself to another person." ${ }^{\prime 89}$ Likewise, when it comes to the possession of a sexted image, the Louisiana law also applies only to those individuals under the age of seventeen. ${ }^{90}$ This means that a seventeen-year-old boy or girl who sexts an image of himself or herself is treated as an adult and is not eligible for prosecution under Louisiana's new sexting law.

\footnotetext{
${ }^{87}$ An Act Concerning Criminal Law, Act of July 19, 2010, Pub. Act. No. 096-1087, § 3-40(a), Ill Laws (2010) (Reg. Sess.), available at http://www.ilga.gov/legislation/publicacts/96/PDF/096-1087.pdf.

88 Id.

${ }^{89}$ LA. Rev. StAT. ANN. § 14:81.1.1(A)(1) (2010) (emphasis added).

${ }^{90}$ LA. REV. STAT. ANN. § 14:81.1.1(A)(2) (2010).
} 
Although Louisiana's law differs from the Arizona and Illinois measures on the element of age by lowering eligibility for the offense of sexting to those under the age of seventeen, rather than those under the age of eighteen, it nonetheless mirrors the approaches of Arizona and Illinois by treating all minors under that threshold in a similar, one-size-fits-all manner.

\section{Summary}

When it come to the element of age, Connecticut's statute stands apart from the sexting laws adopted in other states in 2010 by taking a very nuanced approach rather than treating all minors alike. Arizona and Illinois simply define those qualifying for the offense of sexting as individuals under eighteen years of age, while Louisiana's sexting law applies to individuals under seventeen years of age.

Seventeen-year-old minors thus are subjected to the vagaries of geography - at least in terms of whether they can be charged with sexting or whether they may face prosecution as an adult for child pornography. In other words, a seventeen-year-old boy who sexts in either Arizona or Illinois could be prosecuted for the offense of sexting in those states, but would not be subject to it in Louisiana because he is too old to fall within the scope of its sexting law.

\section{Remedies and Punishments}

Punishment for the crime of child pornography is severe in the United States. For instance, federal law mandates a minimum of fifteen years in prison for first-time offenders who produce and create child pornography ${ }^{91}$ and a minimum of five years in prison for those who distribute or possess it. ${ }^{92}$ Such harsh remedies seem disproportionate and inappropriate for

\footnotetext{
${ }^{91} 18$ U.S.C. $\S 2251$ (e) (2006).

9218 U.S.C. $\S 2252$ (b)(1) (2006).
} 
minors who sext, given that child pornography laws were intended to protect minors from adults and sexual predators. ${ }^{93}$

But what is an appropriate and proportionate remedy for minors who sext? Should they be incarcerated, fined and/or ordered to perform community service? What is the appropriate remedy for the offense of sexting?

This section illustrates how the four states that adopted sexting laws in 2010 took different approaches in resolving these issues. What all of the approaches have in common, however, is that they do not treat sexting as a felony. This is crucial not only because it reduces the length of possible incarceration and monetary fine for sexting, but also because it eliminates the stigma that would come with being a registered sex offender like Philip Alpert. ${ }^{94}$

\section{Arizona: Petty Offenses and Misdemeanors}

Arizona treats juveniles who transmit sexted images in a slightly different fashion from juveniles who possess those images. In both instances, however, the punishment is anything but harsh, at least when compared to the punishment imposed under Arizona's child pornography laws, which classify the sexual exploitation of a minor as a class two felony. ${ }^{95}$

How harsh are Arizona's child pornography laws? Arizona statutes mandate that “consecutive sentences must be imposed for each conviction involving children under fifteen, and each such sentence carries a minimum term of ten years, a presumptive term of seventeen years, and a maximum term of twenty-four years." 96 Furthermore, the Arizona Supreme Court in 2006 held that a defendant's total sentence of 200 years, which was ten years for each count of

\footnotetext{
${ }^{93}$ Supra note 17 and accompanying text.

${ }^{94}$ See supra notes 26-27 and accompanying text (discussing Philip Alpert).

95 ARIZ. REV. STAT. ANN. $§ 13-3553$ (C) (2010) (providing that "sexual exploitation of a minor is a class 2 felony").

${ }^{96}$ Arizona v. Berger, 134 P.3d 378, 379 (Ariz. 2006).
} 
child pornography, was not disproportionate or violative of the Eighth Amendment ${ }^{97}$ because the sentence was tied directly to the Arizona legislature's effort to deter production and distribution of child pornography. ${ }^{98}$ As Subsections a and b below make clear, the offense of sexting is treated with a much lighter touch.

\section{a. Transmission and Display of Sexted Images}

The level of punishment in Arizona for a juvenile who intentionally or knowingly transmits a sexually explicit image is determined by the scope of dissemination of that image. In particular, if a juvenile transmits or displays the image to only one other person, then his or her conduct is treated as a mere petty offense. ${ }^{99}$ But if the scope of transmission or display extends beyond more than one individual, then the statute ratchets up the punishment to a class three misdemeanor. ${ }^{100}$ Parsed differently, Arizona creates a dissemination dichotomy: one image versus more than one image.

What is the difference between a petty offense and a class three misdemeanor? Under Arizona law, a petty offense is "an offense for which a sentence of a fine only is authorized by law."101 In contrast, a class three misdemeanor involves the possibility of jail time, as it is punishable by up to thirty days in jail and a $\$ 500$ fine. ${ }^{102}$

Punishment is ramped up, however, for repeat sexting offenders. In particular, the

\footnotetext{
${ }^{97}$ The Eighth Amendment provides that "excessive bail shall not be required, nor excessive fines imposed, nor cruel and unusual punishments inflicted." U.S. CONST. amend. VIII.

${ }^{98}$ Berger, 134 P.3d at 388.

${ }^{99}$ ARIZ. REV. STAT. ANN. § 8-309(D) (2010).

${ }^{100} \mathrm{Id}$.

${ }^{101}$ ARIZ. ReV. StAT. ANN. § 13-105(30) (2010).

102 See ARIZ. REV. STAT. ANN. § 13-707(A)(3) (2010) (providing that the "sentence of imprisonment for a misdemeanor shall be for a definite term to be served other than a place within custody of the state department of corrections" and that the maximum limitation for a class three misdemeanor is "thirty days"); ARIZ. REV. STAT. ANN. $§ 13-802(C)$ (2010) (providing that "a sentence to pay a fine for a class 3 misdemeanor shall be a sentence to pay an amount, fixed by the court, not more than five hundred dollars").
} 
Arizona law provides that "any violation of this section that occurs after adjudication for a prior violation of this section or after completion of a diversion program as a result of a referral or petition charging a violation of this section is a class 2 misdemeanor."103 A person convicted of a class two misdemeanor faces up to four months in jail and payment of a fine capped at $\$ 750{ }^{104}$

This tiered-penalty approach - where first-time offenders receive relatively minor penalties while serial sexters face stiffer sentences - mirrors federal child pornography laws that also increase punishment for repeat offenders. ${ }^{105}$

\section{b. Possession of Sexted Images}

Arizona treats the knowing possession by a juvenile of a sexually explicit image of a minor that was transmitted to the juvenile through the use of an electronic communication device as a petty offense. ${ }^{106}$ Unlike the offense of transmitting such an image of a minor, there is no escalation of the penalty to a class three misdemeanor for possessing more than one image. However, as with the transmission of sexted images, the penalty is enhanced to a class two misdemeanor if a juvenile already has a prior sexting offense. ${ }^{107}$

\section{Connecticut: Class A Misdemeanor}

Connecticut's law treats both the knowing possession and the knowing transmission by minors of sexted images as class A misdemeanors. ${ }^{108}$ Individuals found guilty of a class A

\footnotetext{
${ }^{103}$ ARIZ. REV. StAT. ANN. § 8-309(F) (2010) (emphasis added).

${ }^{104}$ See ArIZ. REV. StAT. ANN. § 13-707(A)(2) (2010); ARIZ. REV. StAT. AnN. § 13-802(B) (2010) (providing that "a sentence to pay a fine for a class 2 misdemeanor shall be a sentence to pay an amount, fixed by the court, not more than seven hundred fifty dollars").

${ }^{105}$ See 18 U.S.C. $\S 2252$ (2006).

${ }_{106}$ ARIZ. REV. STAT. ANN. § 8-309(E) (2010).

107 ARIZ. REV. StAT. AnN. § 8-309(F) (2010).

${ }^{108}$ An Act Concerning Sexting, Pub. Act. No. 10-191, § 1, 2010 Conn. Acts (2010) (Reg. Sess.), available at http://www.cga.ct.gov/2010/ACT/PA/2010PA-00191-R00HB-05533-PA.htm.
} 
misdemeanor are subject to incarceration for up to a year in jail and payment of a fine of up to \$2000. ${ }^{109}$ This is significantly greater than Arizona's petty offense categorization for both the transmission of a single sexted image or the possession a sexted image, ${ }^{110}$ as those found guilty of a petty offense in Arizona are subject only to a fine, not incarceration.

\section{Illinois: Counseling and Community Service}

Rather than categorizing sexting as either a petty offense or a misdemeanor, Illinois treats minors who distribute or disseminate an indecent visual depiction of another minor through the use of a computer or electronic communication device as subject to adjudication as "a minor in need of supervision." ${ }^{111}$ Rather than leading to a fine or incarceration, this designation requires a minor who sexts to either attend counseling or to perform community service. ${ }^{112}$

Despite the seeming leniency of such punishments, the Illinois measure includes the critical caveat that "nothing in this Section shall be construed to prohibit a prosecution for disorderly conduct, public indecency, child pornography, a violation of the Harassing and Obscene Communications Act, or any other applicable provision of law."113 In other words, a minor in Illinois who sexts may be subject not only to its new sexting law, but also to its much harsher child pornography and obscenity statutes. ${ }^{114}$ Child pornography, under Illinois statute, is a class one felony, ${ }^{115}$ a single count of which merits four to fifteen years in a state penitentiary. This provides prosecutors with substantial flexibility to determine what is in the best interest not

\footnotetext{
${ }^{109}$ Conn. Gen. Assembly, Office of Legislative Research, Summary of 2008 Public Acts iii (2008), available at http://www.cga.ct.gov/olr $/ 2008 \% 20 \mathrm{PA} \% 20 \mathrm{Book} / 2008$ PA_Book.pdf.

${ }^{110}$ Supra Part I, Section C, Subsection 1.

${ }^{111}$ An Act Concerning Criminal Law, Act of July 19, 2010, Pub. Act. No. 096-1087, § 3-40(b), Ill. Laws (2010) (Reg. Sess.), available at $\mathrm{http://www.ilga.gov/legislation/publicacts/fulltext.asp?Name=096-1087 \& GA=96.}$

${ }^{112} I d$

${ }^{113} \mathrm{Id}$

${ }^{114}$ See 720 Ill. COMP. Stat. 5/11-20 (2010) (defining the offense of obscenity in Illinois); 720 ILL. COMP. STAT. 5/11-20.1 (2010) (defining the offense of child pornography in Illinois).

${ }^{115} 720$ ILL. COMP. STAT. 5/11-20.1 (2010) (defining the offense of child pornography in Illinois).
} 
only of the minor who sexts, but also of the citizens of Illinois who may be harmed by that minor.

\section{Louisiana: Fines, Jail and Community Service}

Like Arizona, ${ }^{116}$ Louisiana treats the transmission of sexted images in a different fashion from the possession of such images. In particular, when it comes to minors who knowingly transmit indecent visual depictions of themselves, Louisiana's new sexting measure provides that their "disposition shall be governed exclusively by the provisions of Title VII of the Louisiana Children's Code." 117 Title VII covers Families in Need of Services (FINS) and governs socalled "self-destructive behaviors by the child."118 A multitude of dispositional alternatives exist under Title VII, including ordering the child to submit to counseling and placing "the child on probation on such terms and conditions as deemed in the best interests of the child and the

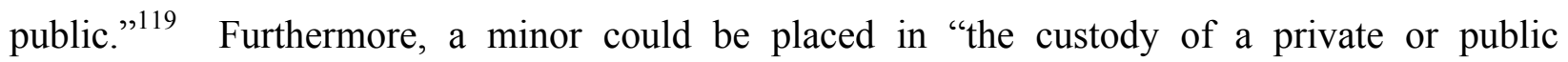
institution or agency, except that the child shall not be placed in a correctional facility designed and operated exclusively for delinquent children." ${ }^{, 120}$

In contrast, when it comes to the possession of an electronically transmitted indecent visual image, Louisiana's statute provides that:

The offender shall be fined not less than one hundred dollars nor more than two hundred fifty dollars, imprisoned for not more than ten days, or both. Imposition or execution of the sentence shall not be suspended unless the offender is placed on probation with a minimum condition that he perform two eight-hour days of courtapproved community service. ${ }^{121}$

\footnotetext{
${ }^{116}$ Supra Part I, Section C, Subsection 1.

${ }^{117}$ LA. REV. STAT. ANN. § 14:81.1.1(C)(1) (2010).

${ }^{118}$ LA. CHILD. CODE ANN. art. 726 (2010).

${ }^{119}$ LA. CHILD. CODE ANN. art. 779 (2010).

${ }^{120} \mathrm{Id}$.

${ }^{121}$ LA. ReV. StaT. ANN. § 14:81.1.1(C)(2)(a) (2010).
} 
This suspended-sentence approach allows a minor who possesses a sexted image to elude

both jail and a fine if he or she performs at least sixteen hours of community service. ${ }^{122}$ The statute specifies that such service is a "minimum condition," thus providing a judge with flexibility to impose more hours of community service if it is deemed appropriate.

In contrast to the penalties for sexting, Louisiana's generally applicable child pornography law provides that "whoever commits the crime of pornography involving juveniles shall be fined not more than ten thousand dollars and be imprisoned at hard labor for not less than two years or more than ten years, without benefit of parole, probation, or suspension of sentence." ${ }^{123}$

\section{Summary}

While the four states that adopted sexting statutes in 2010 differ in the specifics of how they treat or punish minors who sext, they all have one thing in common - substantially reduced penalties compared to those for the crimes for transmitting and possessing child pornography. From minimal fines to relatively short periods of incarceration, and from suspended sentences to court-ordered counseling and community service, the sexting laws in Arizona, Connecticut, Illinois and Louisiana all treat minors like minors, rather than like hardened criminals. At the most, some of the states treat sexting as a petty offense or misdemeanor offense; none of the states, however, treat it as a felony. Such reduced penalties were, of course, the impetus for

\footnotetext{
${ }^{122} I d$.

${ }^{123}$ LA. ReV. STAT. ANN. § 14:81.1 (2010).
} 
creating a new category of laws for minors who sext rather than punishing them with the force of more oppressive child pornography statutes. ${ }^{124}$

\section{Defenses and Mitigating Factors to the Crime of Sexting}

It is not uncommon for laws targeting sexually explicit images of minors to include either defenses or mitigating factors. For instance, federal child pornography statutes afford certain defendants charged with possession of child pornography the opportunity to raise an affirmative defense. Such a defense may arise when:

the defendant (1) possessed less than three matters containing any visual depiction proscribed by that paragraph; ${ }^{125}$ and (2) promptly and in good faith, and without retaining or allowing any person, other than a law enforcement agency, to access any visual depiction or copy thereof - (A) took reasonable steps to destroy each such visual depiction; or (B) reported the matter to a law enforcement agency and afforded that agency access to each such visual depiction. ${ }^{126}$

It therefore seems likely that the state sexting laws would provide similar defenses or mitigating factors to reduce or remove the penalties of being charged with sexting, as the federal law has done with child pornography. However, as is further developed below, that is not the case in two of the four states that enacted sexting laws in 2010.

In what ways, if any, have these states provided defenses or mitigating factors to the crime of sexting?

\footnotetext{
${ }^{124}$ See supra notes $15-17$ and accompanying text (describing the seemingly unjust use of child pornography laws to punish teens who sext).

${ }_{125}$ This refers to 18 U.S.C. $\S 2252(a)(4)$ (2006).

${ }^{126} 18$ U.S.C. $\$ 2252$ (c) (2006).
} 


\section{Arizona: Defenses of Destroying, Eliminating or Reporting The Offending Images for Innocent Recipients}

When it comes to the availability of affirmative defenses for sexting, Arizona makes an important distinction between the transmission of sexted images and the possession of sexted images. In particular, Arizona does not provide any affirmative defenses for minors who intentionally or knowingly transmit or display sexted images. In contrast, the state does offer an affirmative defense for minors who intentionally or knowingly possess a sexted image that was transmitted to them by an electronic communication device like a cell phone. ${ }^{127}$

According to the new Arizona law, a juvenile-possessor of a sexted image may raise an affirmative defense if he or she:

- "did not solicit the visual depiction" $" 128$ and

- "took reasonable steps to destroy or eliminate the visual depiction or report the visual depiction to the juvenile's parent, guardian, school official or law enforcement officer." 129

While this language mirrors the federal child pornography law at its core, Arizona's statute seems to use simpler language than the federal statute to describe the circumstances under which an individual would be able to raise an affirmative defense.

One clear difference, however, relates to what may be thought of as numerosity component. In particular, the federal child pornography statute allows an affirmative defense

${ }^{127}$ The new law provides:

It is not a violation of Subsection B of this section if all of the following apply:

1. The juvenile did not solicit the visual depiction. 2. The juvenile took reasonable steps to destroy or eliminate the visual depiction or report the visual depiction to the juvenile's parent, guardian, school official or law enforcement official.

ARIz. REV. StAT. ANN. § 8-309(C) (2010) (emphasis added). Subsection B referenced here relates to the possession - not the transmission - of sexted images. See ARIZ. Rev. STAT. AnN. § 8-309(B) (2010) (providing that it is "it is unlawful for a juvenile to intentionally or knowingly possess a visual depiction of a minor that depicts explicit sexual material and that was transmitted to the juvenile through the use of an electronic communication device") (emphasis added).

${ }_{128}$ ARIZ. REV. STAT. ANN. § 8-309(C)(1) (2010).

${ }^{129}$ ARIZ. REV. STAT. ANN. § 8-309(C)(2) (2010). 
only if the defendant "possessed less than three matters containing" the Arizona statute fails to include a similar numerical cap or ceiling on the maximum number of sexted images a juvenile may possess in order to assert an affirmative defense. In other words, a minor in Arizona who conceivably receives and possesses dozens and dozens of sexted images still could raise an affirmative defense, provided that he or she did not solicit them and that he or she later deletes them or reports them to a designated authority figure.

In summary, the Arizona law provides an affirmative defense only to what the authors of this article call innocent recipients of sexted images - namely minors who did not request or ask for them - by requiring that "the juvenile did not solicit the visual depiction."131 In contrast, what might be called guilty recipients - minors who specifically sought out or asked to receive a sexted image - cannot assert an affirmative defense, even if they either delete the image or, colloquially speaking, if they rat out the sender to an authority figure, be it a parent, a teacher or a law enforcement officer. ${ }^{132}$

One potential problem or loophole with the Arizona affirmative defense, in the opinion of the authors of this article, is that it fails to include a timeliness component. In particular, it simply states that a juvenile must take "reasonable steps to destroy or eliminate the visual depiction or report the visual depiction to the juvenile's parent, guardian, school official or law enforcement official."133 This fails to specify when such reasonable steps must occur. In other words, how long can a minor in Arizona knowingly possess such images before his or her ability to assert the affirmative defense no longer exists? Without any limiting language, the time would seem to be infinite. In contrast, the federal child pornography statute set forth at the start

\footnotetext{
${ }^{130} 18$ U.S.C. $\S 2252(\mathrm{c})(2006)$.

${ }^{131}$ ARIZ. REV. STAT. ANN. § 8-309(C)(1) (2010).

132 Ariz. REV. StAT. AnN. § 8-309 (C)(2) (2010).

${ }^{133} \mathrm{Id}$.
} 
of this section allows an affirmative defense only if the defendant acted "promptly and in good faith." 134

Lawmakers in Arizona therefore might be wise, in the near future, to amend the state's current affirmative defense phrasing of "took reasonable steps to destroy or eliminate the visual depiction"135 to the time-sensitive terminology of "took prompt and reasonable steps to destroy or eliminate the visual depiction."

\section{Connecticut: Tracking Federal Affirmative Defenses}

The Connecticut sexting statute follows the federal child pornography law even more closely than Arizona's sexting law when it comes to affirmative defenses. In particular, the Connecticut measure provides an affirmative defense for sexting if three conditions - two of which track the federal child pornography statute - are satisfied.

In line with the federal law, Connecticut allows an affirmative defense for sexting only if the defendant:

- "possessed fewer than three visual depictions of child pornography,"136 and

- "promptly, and in good faith, and without retaining or allowing any person . . to access any visual depiction or copy thereof, took reasonable steps to destroy each such visual depiction or reported the matter to a law enforcement agency and afforded that agency access to each visual depiction."

The Connecticut law also adds a third hurdle for a sexting defendant to clear before he or she can successfully assert an affirmative defense. In particular, an affirmative defense only applies if the defendant "did not knowingly purchase, procure, solicit or request such visual

\footnotetext{
13418 U.S.C. $\S 2252$ (c) (2006) (emphasis added).

135 ARIZ. REV. STAT. ANN. § 8-309(C)(2) (2010).

${ }^{136}$ CONN. GEN. STAT. $§ 53 \mathrm{a}-196 \mathrm{~g}(1)(\mathrm{A})(2010)$.

${ }^{137}$ Conn. Gen. STAT. $§$ 53a-196g(1)(C) (2010).
} 
depictions or knowingly take any other action to cause such visual depictions to come into the defendant's possession."138 This language is important because it confines the scope of the affirmative defense to only innocent recipients of sexted images - specifically minors who did not request or ask for them. If a minor knowingly requests or asks for a sexted image, then the affirmative defense is eviscerated.

Finally, Connecticut's sexting law provides that it is not an offense for a defendant to possess "a visual depiction of a nude person under sixteen years of age" if such possession is "for a bona fide artistic, medical, scientific, educational, governmental or judicial purpose.",139 Such language, which reflects a saving provision for sexually explicit speech that is much like the third-prong of the test for obscenity fashioned by the United States Supreme Court in Miller v. California, ${ }^{140}$ is not unusual when it comes to laws targeting possession of sexually explicit images of minors. For instance, Virginia's child pornography law makes an exception for "material that is possessed for a bona fide medical, scientific, governmental, or judicial purpose by a physician, psychologist, scientist, attorney, or judge who possesses such material in the course of conducting his professional duties as such."141 Ohio includes similar language in its child pornography statute as well. ${ }^{142}$

\footnotetext{
${ }^{138}$ CONN. GEN. STAT. § 53a-196g(1)(B) (2010).

${ }^{139}$ CONN. GEN. STAT. \$53a-196g(2) (2010).

140413 U.S. 15 (1973). The third prong of the Miller test requires fact finders in obscenity cases to determine if the material has serious literary, artistic, political or scientific value. Id. at 24.

${ }^{141}$ VA. CODE ANN. § 18.2-374.1:1(F) (2010).

${ }^{142}$ Ohio law provides a defense if the material under possession:

is sold, disseminated, displayed, possessed, controlled, brought or caused to be brought into this state, or presented for a bona fide artistic, medical, scientific, educational, religious, governmental, judicial, or other proper purpose, by or to a physician, psychologist, sociologist, scientist, teacher, person pursuing bona fide studies or research, librarian, member of the clergy, prosecutor, judge, or other person having a proper interest in the material or performance.
}

OHIO REV. CODE. ANN. § 2907.323(A)(3)(a) (2010) (emphasis added). 


\section{Illinois and Louisiana: No Defenses or Mitigating Factors}

Unlike Arizona and Connecticut, neither Illinois nor Louisiana provides any affirmative defense to the crime of sexting in their new statutes. This might be because both Illinois and Louisiana offer opportunities, but not requirements, for judges to reduce the penalties for minors found guilty of sexting, and allow them to elude the harsher punishments of fines or jail time by taking part in or fulfilling their responsibilities of attending counseling or performing community service. $^{143}$

\section{Summary}

While Arizona and Connecticut both provide an affirmative defense to a person charged with sexting that, more or less mirrors the same affirmative defense provided under the federal child pornography statute, Illinois and Louisiana fail to include a similar affirmative defense or, for that matter, any affirmative defense. Whether such a split among states persists in coming years on the issue of whether to enumerate statutory affirmative defenses to sexting remains, of course, to be seen.

\section{A Different Kind of Affirmative Defense For Consensual Sexting? The Dating and Courtship Defense}

Among the states that considered sexting-related bills in 2010 but that did not ultimately adopt a sexting law, Indiana and Oklahoma stand out, in part because they offered an approach based solely upon the assertion of a sexting-based affirmative defense by minors to their generally applicable state child pornography laws. In particular, rather than adopting a statute that articulates a new offense called sexting, Indiana House Bill 1115 would have allowed

\footnotetext{
${ }^{143}$ Supra Part I, Section C, Subsections 3-4.
} 
minors who sext to assert a defense to a child pornography charge if they could prove all five of the following criteria:

(1) A cellular telephone, another wireless or cellular communications device, or a social networking web site was used to possess, produce, or disseminate the image; (2) The defendant is not more than four (4) years older or younger than the person who is depicted in the image or who received the image; (3) The relationship between the defendant and the person who received the image or who is depicted in the image was a dating relationship or an ongoing personal relationship. For purposes of this subdivision, the term "ongoing personal relationship" does not include a family relationship; (4) The crime was committed by a person less than twenty-one (21) years of age; [and] (5) The person receiving the image or who is depicted in the image acquiesced in the defendant's conduct. ${ }^{144}$

This approach is important because, among the quintet of factors necessary for the assertion of a defense, are two that none of the four states that passed sexting laws in 2010 included but that, nonetheless, seem logical for adoption, namely:

- the existence of a dating or an ongoing personal relationship between the sexters; and

- the acquiescence by the non-charged sexting party to the defendant's conduct.

The dating-relationship factor is significant because it recognizes that sexting today among some teens is viewed as little more than part of the natural process of flirting and courtship. ${ }^{145}$ As a March 2009 MacLean's article put it, "what U.S. law enforcement views as pornography, teenagers see as high-tech flirting." ${ }^{" 146}$ For instance, Melanie Young of Texas, who

\footnotetext{
${ }^{144}$ A Bill for An Act to Amend the Indiana Code concerning criminal law and procedure, H.B. 1115, IC 20-3-6-6 § 4(e) 116th Gen. Assem., 2d Reg. Sess. (Ind. 2010), available at http://www.in.gov/legislative/bills/2010/IN/IN1115.1.html. girl, might send out nude photos of her to friends as proof").

${ }_{146}$ Anne Kingston, The Sexting Scare, MACLEAN'S, Mar. 16, 2009, at 52, available at http://www2.macleans.ca/2009/03/12/the-sexting-scare/. See also World News with Charles Gibson (ABC television broadcast Mar. 13, 2009) (observing that for some teens, sexting is "little more than a high tech way of flirting").
} 
sent a nude photograph of herself to a boy when she was sixteen years old, told a reporter for the Dallas Morning News that she "thought it was fun and just a way of flirting." 147 When this relationship factor is coupled with the second of the two bullet-pointed factors - that the person receiving the image or depicted in the image acquiesced in the defendant's conduct - it is clear that Indiana is attempting to shield from prosecution only those teens who engage in what the authors of this article call consensual, courtship sexting.

This type of an affirmative defense makes sense in its application because it does not protect the pernicious type of downstream sexting that occurs when a couple breaks up and the spurned teen lover sends out his ex-girlfriend's photograph to others as a form of revenge. ${ }^{148}$ For instance, imagine that sixteen-year-old Jill is charged with creating and distributing child pornography. The charge, however, stems from the fact that Jill used her cell phone to send 15year-old Jack a nude photograph of herself suggestively touching her vagina. If Jill and Jack have been dating for a month, and Jack acquiesces in the receipt of the image, then the defendant (Jill) might be able to assert an affirmative defense. But if the two later break up and Jack angrily sends Jill's photo out to five of his best guy friends, then Jack would not be able to assert an affirmative defense if he is charged with distributing child pornography because Jack and his buddies are not involved a dating relationship and Jill did not acquiesce to the forwarding of her image.

Similar to Indiana's approach, Oklahoma House Bill 3321, which was introduced in February 2010 but never gained traction, would have reduced the penalty for possessing child pornography from a felony to a misdemeanor if:

\footnotetext{
${ }^{147}$ Megan Goodson, Keeping Teens From Hitting 'Send, 'Dallas Morning News, Aug. 24, 2009 , at A1.

${ }^{148}$ See Tom Barnes, 'Sexting” is No Felony, Bill Says, PitTsburgh Post-GazetTe, Jan. 25, 2010, at A-1 (observing that sexting "can get especially nasty if a young couple breaks up and one of them begins sending the nude photos of their ex-girlfriend or boyfriend to other people, as an act of spite or revenge").
} 
one of the persons is eighteen (18) years of age or older, is currently in a courtship, dating or engagement relationship with the other person and the other person is not under the age of fourteen (14), or when both persons are not under the age of fourteen (14) but are less than the age of eighteen (18). ${ }^{149}$

While the Oklahoma bill, were it to have become law, might have suffered from a voidfor-vagueness ${ }^{150}$ problem because it failed to define the seemingly flexible terms "courtship" and "dating," both it and the Indiana measure should be lauded for recognizing a difference between consensual and non-consensual sexting, and, in turn, attempting to provide either an affirmative defense or penalty reduction for the former.

\section{E. Some Different Approaches Considered in 2010 that Failed to Become Law}

Although Arizona, Connecticut, Illinois and Louisiana were the only states that had passed laws in 2010 targeting the offense of sexting, there were some inventive and markedly different approaches considered by other states that ultimately failed to become law. For instance, New Jersey Assembly Bill 1562 would have placed a burden on businesses - namely cell phone retailers - to enclose "an information brochure with such equipment or contract that informs the individual about the dangers of the practice known as "sexting.",151 Besides foisting an education burden on businesses, the New Jersey bill was one of the few in 2010 that actually used the term "sexting," which it defined as "the act of sending sexually explicit messages or

\footnotetext{
${ }^{149}$ An Act relating to crimes and punishment; amending 21 O.S. 2001, Section 1040.13a, as last amended by Section 14, Chapter 261, O.S.L. 2007 (21 O.S. Supp. 2009, Section 1040.13a), which relates to solicitation of sexual conduct or communication with a minor by use of technology; including description of text messages with certain sexual content; modifying penalty for consensual text messages between certain persons; specifying penalty for certain persons; and declaring an emergency, H.B. 3321, 52d Leg., 2d Sess., § 1(E)(1)(a) (Okla. 2010), available at http://webserver1.lsb.state.ok.us/2009-10HB/HB3321 int.rtf (emphasis added).

${ }^{150}$ See Grayned v. City of Rockford, 408 U.S. 104, 108 (1972) (observing that "it is a basic principle of due process that an enactment is void for vagueness if its prohibitions are not clearly defined" such that they fail to "give the person of ordinary intelligence a reasonable opportunity to know what is prohibited").

${ }^{151}$ An Act Concerning the sale of cellular telephone equipment and cellular telephone equipment service contracts, and supplementing P.L.1960, c.39 (C.56:8-1 et seq.), Assem. B. 1562, § 2(a), 214th Leg. (N.J. 2010), available at http://www.njleg.state.nj.us/2010/Bills/A2000/1562_I1.HTM.
} 
photos electronically, from one person's cellular telephone equipment to another person's cellular telephone equipment." ${ }^{, 152}$

Calls for educational programs were another tactic that was considered in 2010. For instance, New York Assembly Bill 8622 would have established:

an educational outreach program for text message, email and internet posting awareness by providing for an ongoing public information and educational campaign about the harm that may arise from adolescents sending, receiving or posting on the internet messages that may include, but are not limited to, provocative or nude images and photographs of themselves. ${ }^{153}$

An Indiana bill would have allowed public schools to "offer classes, instruction, or programs regarding the potential risks and consequences of creating and sharing sexually suggestive or sexually explicit materials through cellular telephones, social networking web sites, computer networks, and other digital media." ${ }^{~} 154$

Another tactic was to call for further study of the topic of sexting. For instance, Rhode Island Senate Bill 2871 (Substitute A) called for the creation of a commission "to study and make recommendations to the Senate relating to the problem of cyberthreats, cyberbullying, bullying, and sexting." 155

\footnotetext{
${ }^{152} \mathrm{Id}$.

${ }^{153} \mathrm{An}$ act to amend the executive law and the penal law, in relation to educating children on the electronic sending and posting of certain images, Assem. B. 8622, §1, 1999-2000 Reg. Sess. (N.Y. 2010), available at http://assembly.state.ny.us/leg/?default fld $=\& b n=A 08622 \& T e x t=Y$.

${ }^{154} \mathrm{~A}$ Bill for An Act to Amend the Indiana Code concerning criminal law and procedure, H.B. 1115, IC 20-3-6-6 § 6, 116th Gen. Assem., 2d Reg. Sess. (Ind. 2010), available at http://www.in.gov/legislative/bills/2010/IN/IN1115.1.html.

${ }^{155}$ Creating a Special Senate Commission to Study and Make Recommendations Related to the Problem of Cyberthreats, Cyberbullying, Bullying, and Sexting, S. Res. 2871 Sub. A, Gen. Assem., Jan. Sess. (R.I. 2010), available at $\mathrm{http}$ ://dirac.rilin.state.ri.us/BillStatus/WebClass1.ASP?WCI=Bills\&WCE=BillEvent\&WCU=S2871A.
} 


\section{II. \\ FROM THEORY TO REALITY: Applying the Four New Laws to a Realistic Sexting Scenario To Explore Their Strengths, Weaknesses AND Differences}

All of the sexting laws adopted in 2010 require the use of a computer, cell phone or another electronic communication device, in order for a minor to be successfully prosecuted for the offense of sexting. Sexting is a technology-specific crime; the mode of communication is a critical element of the offense. In other words, how a message is communicated, transmitted or received makes all of the difference in terms of whether or not the offense of sexting may have occurred.

What happens, however, if a minor who receives a sexually explicit image of another minor via a cell phone later decides to print it out and then to distribute hard copies of it to his minor friends? Has a crime occurred? Have several crimes occurred? Are the following people responsible for having committed a crime: a) the minor sender?; b) the minor recipient?; and/or c) the downstream minor friends to whom hard copies of the image are given? Do the answers to these questions depend upon the state where the minors are located - Arizona, Connecticut, Illinois or Louisiana?

To address these questions and to better understand the differences among the four sexting statutes signed into law in 2010, it is helpful to consider, in classic law school fashion, a hypothetical. Undertaking this kind of analysis also helps to demonstrate strengths and weaknesses with the sexting statutes in Arizona, Connecticut, Illinois and Louisiana. 


\section{A. The Hypothetical Fact Pattern}

Consider the following not so far-fetched scenario: 1) Jack (sixteen years old) receives a sexually explicit image of his girlfriend, Jill (seventeen years of old), that she has freely and voluntarily sent to his cell phone via her own cell phone; 2) Jack is initially shocked because he had never asked her for such an image, which depicts her touching her splayed vagina, and because she had not sent him anything like it before until now; 3) after receiving the image of Jill, however, Jack quickly forwards it from his cell phone to his home computer; 4) Jack next prints out a dozen color copies of Jill's sexually explicit image on his home computer's printer; 5) four days later, Jack then deletes from both his cell phone and his computer the sexually explicit image of Jill; 6) the next day, Jack meets up with four of his best guy friends (all are fifteen years old) after school and he shows them the picture of Jill; 7) two of Jack's friends, Johnny and Jeremy, ask for copies of the photograph of Jill, which Jack gives them, and Jack

then passes out copies to the other two minors, Bob and Biff, even though they have not asked for them; and 8) Johnny, Jeremy, Bob and Biff keep the photos for themselves and do not show them or give them to anyone else.

What offenses, if any, may have occurred under the laws adopted in 2010 by Arizona, Connecticut, Illinois and Louisiana, assuming arguendo that the level of the sexual explicitness of the image of Jill satisfies the minimum threshold required for sexting in each of the four states? To more clearly address this issue, it is helpful to analyze the scenario on a possibleperpetrator-by-possible-perpetrator basis. 


\section{B. Jill: The Initial Electronic Sender}

Whether Jill is subject to prosecution for the offense of sexting depends upon the state in which she resides. The first key fact from the hypothetical that must be considered is her age Jill is seventeen years old. She thus falls within the age range of minors subject to prosecution for sexting in Arizona and Illinois, both of which define those qualifying for the offense of sexting as individuals under eighteen years of age. ${ }^{156}$

Jill, however, does not fall within the sweep of Louisiana's sexting statute, which provides that "no person under the age of seventeen years shall knowingly and voluntarily use a computer or telecommunication device to transmit an indecent visual depiction of himself to another person." ${ }^{, 157}$ Because Jill is not under the age of seventeen years, she is one year too old for prosecution for sexting in Louisiana and, instead, would be subject to prosecution under that state's generally applicable child pornography laws - laws that require a minimum of two years in prison, without the possibility of parole, for a single offense - should a district attorney there decide to press charges against her. ${ }^{158}$

Jill also is too old for prosecution for transmitting a sexted image in Connecticut. As described earlier, Connecticut's new sexting law provides that "no person who is thirteen years of age or older but under sixteen years of age may knowingly and voluntarily transmit by means of an electronic communication device a visual depiction of child pornography." ${ }^{159}$ Because Jill is seventeen years of age, she is two years too old to fall within the sweep of this language. She could, however, be subject to the much harsher strictures of and penalties imposed by

\footnotetext{
${ }^{156}$ Supra Part I, Section C, Subsection 5.

${ }^{157}$ LA. REV. STAT. ANN. § 14:81.1.1(A)(1) (2010) (emphasis added).

${ }^{158}$ See LA. REV. STAT. ANN. § 14:81.1(E)(1) (2010) (providing that "whoever commits the crime of pornography involving juveniles shall be fined not more than ten thousand dollars and be imprisoned at hard labor for not less than two years or more than ten years, without benefit of parole, probation, or suspension of sentence") (emphasis added).

${ }^{159}$ An Act Concerning Sexting, Pub. Act. No. 10-191, § 1, 2010 Conn. Acts (2010) (Reg. Sess.), available at http://www.cga.ct.gov/2010/ACT/PA/2010PA-00191-R00HB-05533-PA.htm (emphasis added).
} 
Connecticut's child pornography laws. ${ }^{160}$

In summary, age is a critical variable under the sexting laws adopted in 2010. Jill falls within the age range of minors targeted for the offense of sexting in both Arizona and Illinois, but is too old for prosecution for sexting in both Connecticut and Louisiana.

This does not, however, end the inquiry or resolve the analysis as to Jill's culpability. The question then becomes: Even if Jill fits within the age range of minors subject to prosecution for sexting in Arizona and Illinois, do her actions satisfy the other elements required for that offense in those two states?

Arizona's sexting law provides, in relevant part, that "it is unlawful for a juvenile to intentionally or knowingly use an electronic communication device to transmit or display a visual depiction of a minor that depicts explicit sexual material." ${ }^{\prime 161}$ The hypothetical notes that Jill freely and voluntarily transmitted the image of herself from her cell phone to Jack, who is sixteen years old. ${ }^{162}$ Jill clearly falls within this language because: 1) she used an electronic communication device to transmit an image; 2) the image, in turn, depicts Jill and she is, at age seventeen, a minor under Arizona law; and 3) the facts assume that "the level of the sexual explicitness of the image of Jill meets and satisfies the minimum level required for sexting in each of the four states." 163

The fact that Jack is sixteen years of age is actually irrelevant, because the Arizona statute targeting the transmission of sexted images says nothing about the requisite age of the recipient of those images. It simply states "it is unlawful for a juvenile to intentionally or

\footnotetext{
${ }^{160}$ See CONN. GEN. STAT. § 53a-196f (2010) (providing that "a person is guilty of possessing child pornography in the third degree when such person knowingly possesses fewer than twenty visual depictions of child pornography" and that "any person found guilty under this section shall be sentenced to a term of imprisonment of which one year of the sentence imposed may not be suspended or reduced by the court").

${ }^{161}$ ARIZ. REV. STAT. ANN. § 8-309(A) (2010).

${ }^{162}$ Supra Part II, Section A.

${ }^{163}$ Supra Part II, Section A.
} 
knowingly use an electronic communication device to transmit or display a visual depiction of a minor that depicts explicit sexual material." ${ }^{\text {164 }}$ The statute makes no reference to a requirement that the images be sent to a particular type of individual.

The analysis of Jill's action still does not end there under the Arizona law because the next step is to consider whether or not she can successfully assert an affirmative defense. However, as noted earlier, Arizona does not provide any affirmative defenses for minors who intentionally or knowingly transmit sexted images; it only provides an affirmative defense for minors who receive such images, who did not solicit them, and who either destroyed or reported them. ${ }^{165}$ Jill therefore lacks an affirmative defense because she transmitted, rather than received, the image in question.

Ultimately, it is clear that Jill could be subjected to prosecution for sexting under the new law in Arizona. If convicted, what penalty would she face?

As noted earlier, Arizona's sexting law creates a dissemination dichotomy: one image versus more than one image. In particular, if a juvenile transmits or displays the image to only one other person, then his or her conduct is treated as a mere petty offense. ${ }^{166}$ But if the scope of transmission or display extends beyond more than just one individual, then the statute ratchets up the punishment to a class three misdemeanor. ${ }^{167}$

The hypothetical mentions only one person - Jack - to whom Jill knowingly transmitted the image of herself. If she did not send it to anyone else, then she would have committed, at most, only a petty offense in Arizona and would face merely a monetary fine and no jail time.

\footnotetext{
${ }^{164}$ ARIZ. REV. STAT. ANN. § 8-309(A) (2010).

${ }_{165}$ Supra Part I, Section D, Subsection 1.

${ }_{166}$ ARIZ. REV. STAT. ANN. § 8-309(D) (2010).

${ }^{167}$ Id.
} 
What about Jill's potential culpability under the Illinois law, the only other state besides Arizona, subjecting someone of her age - seventeen years old- to possible prosecution? The Illinois statute provides, in relevant part, that "a minor shall not distribute or disseminate an indecent visual depiction of another minor through the use of a computer or electronic communication device." ${ }^{\text {168 }}$ The italicized portion of this language is crucial here. Why? Because Jill did not distribute or disseminate a depiction "of another minor." 169 The facts state that she distributed an image of herself. ${ }^{170}$ In other words, she does not seem to fall within the reach of the Illinois statute because of the person depicted in the image. As a self-sexter she escapes liability.

Ultimately, then, of the four states that adopted sexting laws in 2010, Jill seems likely be convicted of sexting in only one of them - Arizona. As this analysis demonstrates, it is not simply the age of the perpetrator that is a crucial element of the newly minted sexting laws. In the case of Illinois, it is the use of the phrase "of another minor" that eliminates Jill's potential culpability for sexting in that state.

\section{Jack: The Initial Electronic Recipient and the Hard-Copy Disseminator}

Could Jack be subject to prosecution under any or all four of the sexting laws adopted in 2010, either for possessing a sexted image or for distributing hard copies of it that he printed out and gave to several of his minor friends?

An initial consideration, similar to Jill's case, is Jack's his age. The hypothetical states

\footnotetext{
${ }^{168}$ An Act Concerning Criminal Law, Act of July 19, 2010, Pub. Act. No. 096-1087, § 3

-40(b) 2010 Ill. Laws (2010) (Reg. Sess.), available at

http://www.ilga.gov/legislation/publicacts/fulltext.asp?Name=096-1087\&GA=96

(emphasis added).

169 Id

${ }^{170}$ Supra Part II, Section A.
} 
that Jack is a sixteen-year-old recipient of the image that Jill sent to him via her cell phone. ${ }^{171}$ As a sixteen-year-old recipient, he falls within the age realm of the sexting laws of all four states - Arizona and Illinois define minors as individuals under the age of eighteen years, while Louisiana's sexting law applies to those under the age of seventeen years. Finally, Connecticut's sexting law aimed at the recipients of images applies to a minor "who is thirteen years of age or older but under eighteen years of age." ${ }^{\prime 72}$ At age sixteen, Jack fits within this window.

\section{Jack's Receipt and Possession of Jill's Image}

With the threshold issue of age resolved, it then is helpful to first concentrate on the issue of Jack's receipt and possession of Jill's image, and then next to address the separate issue of his potential culpability for disseminating that image downstream to his friends.

On the issue of receipt and possession, one state is quickly eliminated from consideration for sexting culpability. In particular, Jack is not subject to liability under Illinois' sexting law because it only targets the distribution and dissemination of sexted images. ${ }^{173}$ That leaves the possibility of prosecution for possession in only Arizona, Connecticut and Louisiana.

Jack would seem to face prosecution under Arizona's sexting statute because that provision makes it "unlawful for a juvenile to intentionally or knowingly possess a visual depiction of a minor that depicts explicit sexual material and that was transmitted to the juvenile

\footnotetext{
${ }^{171}$ Supra Part II, Section A.

${ }^{172}$ An Act Concerning Sexting, Pub. Act. No. 10-191, § 1, 2010 Conn. Acts (2010) (Reg. Sess.), available at http:/www.cga.ct.gov/2010/ACT/PA/2010PA-00191-R00HB-05533-PA.htm.

${ }^{173}$ An Act Concerning Criminal Law, Act of July 19, 2010, Pub. Act. No. 096-1087, § 340(b), 2010 Ill. Laws (2010) (Reg. Sess.), available at http://www.ilga.gov/legislation/publicacts/fulltext.asp?Name $=096-1087 \& \mathrm{GA}=96$ (providing that "a minor shall not distribute or disseminate an indecent visual depiction of another minor through the use of a computer or electronic communication device") (emphasis added).
} 
through the use of an electronic communication device."174 In addition to satisfying the age criterion, Jack meets these elements because: 1) he knowingly possessed of sexually explicit visual depiction of a minor, Jill, who, at age seventeen is a minor under Arizona's sexting statute; and 2) the image was transmitted to Jack by Jill via an electronic communication device.

But Jack may escape liability for possessing the image because Arizona's sexting statute carves out an affirmative defense for possession if a juvenile did "not solicit the visual depiction" 175 and "took reasonable steps to destroy or eliminate the visual depiction or report the visual depiction to the juvenile's parent, guardian, school official or law enforcement official."176 This is a two-part test, the first step of which Jack clearly satisfies because the hypothetical states that "Jack is initially shocked because he had never asked her for such an image."177 Jack, however, appears to be unable to satisfy the second prong of the affirmative-defense test because, although he took steps to eliminate Jill's image from his own cell phone and his computer, he printed out "a dozen color copies of Jill's sexually explicit image on his home computer's printer." ${ }^{178}$ Thus, he only destroyed the visual depiction in one medium - the electronic digital medium of his cell phone and computer - while he duplicated the visual depiction in the tangible, hard copy print medium. Furthermore, the hypothetical never states whether Jack reported the image to an authority figure.

The bottom line therefore seems to be that, although Jack initially was what this article's authors earlier called an innocent recipient ${ }^{179}$ of the image because he did not request it, his subsequent duplication of Jill's image eliminates the possibility of his successful assertion of an

\footnotetext{
${ }^{174}$ ARIZ. REV. STAT. ANN. § 8-309(B) (2010).

${ }_{176}^{175}$ ARIZ. REV. STAT. ANN. § 8-309(C)(1) (2010).

${ }^{176} I d$.

${ }^{177}$ Supra Part II, Section A.

${ }^{178} I d$.

${ }^{179}$ Supra Part I, Section D, Subsection 1.
} 
affirmative defense in Arizona. Ultimately he could be subject to liability for a petty offense for possessing Jill's image. ${ }^{180}$

Turning to Connecticut's law and the question of culpability for his possession of Jill's image, Jack avoids prosecution. Why? Because that law provides liability for a minor of Jack's age for possession only if he:

knowingly possess[es] any visual depiction of child pornography that the subject of such visual depiction knowingly and voluntarily transmitted by means of an electronic communication device to such person and in which the subject of such visual depiction is a person thirteen years of age or older but under sixteen years of age. ${ }^{181}$

Per the facts in the hypothetical, Jill is seventeen years of age. ${ }^{182}$ She thus is not "under sixteen years of age," ${ }^{, 183}$ and Jack cannot be prosecuted for knowingly possessing an image of child pornography under the Connecticut sexting law.

Finally, Jack also fails to fall within the reach of Louisiana's sexting statute based on his possession of Jill's image. That law provides, in relevant part, that "no person under the age of seventeen years shall knowingly possess or transmit an indecent visual depiction that was transmitted by another under the age of seventeen years." 184 This latter language is vital. Why? Because Jill, the person who transmitted the image of herself to Jack, is not "under the age of seventeen years." 185 She is, instead, seventeen.

In summary, despite the adoption of four different sexting laws in 2010, Jack appears subject to conviction under only one them - the law of Arizona - for his possession of Jill's

\footnotetext{
${ }^{180}$ ARIZ. REV. STAT. ANN. § 8-309(E) (2010).

${ }^{181}$ An Act Concerning Sexting, Pub. Act. No. 10-191, § 1, 2010 Conn. Acts (2010) (Reg. Sess.), available at http://www.cga.ct.gov/2010/ACT/PA/2010PA-00191-R00HB-05533-PA.htm (emphasis added).

${ }_{182}$ Supra Part II, Section A.

${ }^{183}$ An Act Concerning Sexting, Pub. Act. No. 10-191, § 1, 2010 Conn. Acts (2010) (Reg. Sess.), available at http://www.cga.ct.gov/2010/ACT/PA/2010PA-00191-R00HB-05533-PA.htm.

${ }^{184}$ LA. REV. STAT. ANN. $§ 14: 81.1 .1(A)(2)$ (2010) (emphasis added). ${ }^{185} \mathrm{Id}$.
} 
image.

But Jack did more than receive and possess Jill's image. The question then becomes: What is Jack's potential culpability for his downstream dissemination of the hard copy reprints of Jill's image to his minor friends? The next subsection addresses this issue.

\section{Jack's Downstream Forwarding of Jill's Image}

If the term "sexting" is a portmanteau of the words sex and texting, then sexting is, by its very definition, a high-technology act, at least to the extent it pivots on the use of a cell phone or smart phone to transmit a digital sexual image. The facts in the hypothetical above, however, involve the downstream dissemination by Jack of Jill's image through a decidedly low-tech method of conveyance - the transfer, via human hand, of a hard copy image. Does the 2010 crop of sexting statutes overlook or fail to sweep up such behavior by a minor who, although initially receiving an image via cell phone, employs a non-electronic vehicle for its further dissemination?

Jack is not liable for transmitting Jill's image under Arizona's sexting statute because that provision only makes it "unlawful for a juvenile to intentionally or knowingly use an electronic communication device to transmit or display a visual depiction of a minor that depicts explicit sexual material."186 Although Jack clearly transmitted and displayed the image of Jill to his friends, he did not use an electronic communication device to do so. Rather, he actually showed and handed the image of Jill to his friends the old-fashioned way - in person, via hand delivery and in a hard copy medium. Jack's decidedly low-tech display and transmission of Jill's image reveals a potential flaw or loophole in Arizona's sexting statute that lawmakers there might consider amending in the future.

${ }^{186}$ ARIZ. REV. STAT. ANN. § 8-309(A) (2010) (emphasis added). 
Similarly, Jack is not subject to the terms of Connecticut's law on the transmission of such images, as it applies only when a minor "knowingly and voluntarily transmit[s] by means of an electronic communication device a visual depiction of child pornography." 187 Likewise, Jack is not subject to Illinois' sexting statute on transmission because it too mandates that "a minor shall not distribute or disseminate an indecent visual depiction of another minor through the use of a computer or electronic communication device." 188

The only state law, in fact, that possibly would seem to address Jack's downstream, lowtech dissemination is that of Louisiana. The portion of the Louisiana sexting law that aims at downstream-sexters provides that "no person under the age of seventeen years shall knowingly possess or transmit an indecent visual depiction that was transmitted by another under the age of seventeen years in violation of the provisions of Paragraph (1) of this Subsection." 189 This language seems, a first glance, to be silent on the particular mode of transmission, thus meaning that it can be via either a high-tech or low-tech mode. Parsed differently, this language appears to be technology neutral. Yet, Jack still is not subject to this provision because it requires the image to initially have been transmitted to him by "another under the age of seventeen years.",190 Because Jill is seventeen years of age - concomitantly, she is not "under" age seventeen - Jack escapes the reach of Louisiana's law here.

But even if Jill were 16 years of age, the Louisiana sexting law still would not apply to Jack's low-tech, downstream transmission of Jill's image. Why? Because a close examination of the statute reveals that it defines the word "transmit" to mean "to give, distribute, transfer,

\footnotetext{
${ }^{187}$ H.B. 5533, Reg. Sess. (Conn. 2010) (enacted) (emphasis added).

${ }^{188}$ An Act Concerning Sexting, Pub. Act. No. 10-191, § 2, 2010 Conn. Acts (2010) (Reg. Sess. October 1, 2010), available at http://www.cga.ct.gov/2010/ACT/PA/2010PA-00191-R00HB-05533-PA.htm (emphasis added).

${ }^{189}$ LA. REV. STAT. ANN. § 14:81.1.1(A)(2) (2010) (emphasis added).

${ }^{190} \mathrm{Id}$.
} 
transmute, circulate, or disseminate by use of a computer or telecommunication device."191 In other words, "transmit" does not include the low-tech, hand-to-hand transmission of the image of Jill in which Jack engaged with his friends.

The bottom line, then, is that Jack is not subject to liability for his transmission of Jill's image under any of the four sexting laws, based on the facts in the hypothetical set forth in Section A of this Part of the article. He might still, however, be charged with a crime under generally applicable child pornography laws in all four states. But one wonders whether such a prosecution for child pornography - as compared to sexting - would again frustrate the intent of child pornography laws that were designed to protect minors from abuse at the hands of adults.

The authors believe that this analysis reveals a flaw - or, at least, a gap - within the 2010 sexting laws. Lawmakers failed to take into account the possibility that the initial recipient of a sexted image might be a minor who later prints out that image and gives hard copies of it to his friends. Lawmakers in Arizona, Connecticut, Illinois and Louisiana thus should considering amending their statutes to account for such low-tech sexting.

The authors dub this possible phenomenon low-tech, downstream sexting, in which the minor depicted in the sexual image becomes a modern-day version of a pin-up girl (or boy) when his or her cell-phone transmitted image moves and morphs from the digital medium to the tangible realm of print. To prosecute the low-tech, downstream sexter for child pornography clearly is one option, but the other choice is to amend the current sexting laws to take into account this possibility.

${ }^{191}$ LA. REV. STAT. ANN. § 14:81.1.1(B)(4) (2010) (emphasis added). 


\section{Jack's Friends: Downstream, Hard-Copy Recipients \& Disseminators}

Jack's friends - the minors to whom he gave Jill's photograph - neither received nor transmitted her image by means of an electronic communication device. Therefore they have not engaged in sexting, at least to the extent that term implies the use of texting and electronic technologies. Rather, they simply seem to be minors who might well possess child pornography.

For instance, under federal law, sexual conduct constituting child pornography includes images that reveal a "lascivious exhibition of the genitals or pubic area of any person." 192 Additionally, under federal child pornography laws, a minor is defined as "any person under the age of eighteen years." 193

Thus, the image possessed by Jack's friends appears to fit this definition because Jill is under the age of eighteen years, and the photograph "depicts her touching her splayed vagina,"194 which could well constitute a lascivious exhibition of the genitals or pubic area under factors commonly applied by many federal courts. ${ }^{195}$

But does this result - prosecuting Jack’s friends for possessing child pornography - make sense? Jack's downstream-recipient friends neither created the child pornography nor reproduced the image of Jill. Perhaps they were simply curious to see what their friend's girlfriend looked like. What's more, neither Bob nor Biff even asked Jack for a copy of Jill's

19218 U.S.C. $\$ 2256(2)(\mathrm{A})(\mathrm{v})(2006)$.

19318 U.S.C. $\S 2256(1)(2006)$.

${ }^{194}$ Supra Part II, Section A.

${ }^{195}$ As a recent federal appellate court ruling observed, many courts apply the six factors established in United States v. Dost, 636 F. Supp. 828, 832 (S.D. Cal. 1986) namely:

1) whether the focal point of the visual depiction is on the child's genitalia or pubic area; 2 ) whether the setting of the visual depiction is sexually suggestive, i.e., in a place or pose generally associated with sexual activity; 3 ) whether the child is depicted in an unnatural pose, or in inappropriate attire, considering the age of the child; 4) whether the child is fully or partially clothed, or nude; 5) whether the visual depiction suggests sexual coyness or a willingness to engage in sexual activity; 6) whether the visual depiction is intended or designed to elicit a sexual response in the viewer.

See also United States v. Brown, 579 F.3d 672, 680 (6th Cir. 2009), cert. denied, 130 S. Ct. 1106 (2010). 
photograph. $^{196}$

Because the facts make it clear that Jack's friends did not engage in any further downstream transmission of the hard-copy images of Jill, ${ }^{197}$ the only way they possibly could be targeted for sexting would be for the possession of an image, not for either its dissemination or distribution. The crop of 2010 sexting laws wouldn't reach Jack's friends. For instance, the Connecticut statute targeting possession provides, in relevant part, that "no person who is thirteen years of age or older but under eighteen years of age may knowingly possess any visual depiction of child pornography that the subject of such visual depiction knowingly and voluntarily transmitted by means of an electronic communication device to such person."198 A careful reading of this statute - one that is cognizant that the words "no person" at the start of the quoted material above refer directly to the words "to such person" used later in that quotation reveals that it only applies when the subject of the visual image (in this case Jill) transmits the image herself to the minor-possessor. Jill did not transmit the image to Jack's friends, nor did she not transmit it to them by means of an electronic communication device.

The Illinois sexting statute does not reach Jack's friends for an even more fundamental reason - it only targets minors who "distribute or disseminate" 199 sexted images, not those who merely possess them. The hypothetical makes it clear that Jack's friends never distributed or disseminated Jill's image. ${ }^{200}$

\footnotetext{
${ }^{196}$ Supra Part II, Section A.

${ }^{197}$ See id. (stating that "Johnny, Jeremy, Bob and Biff keep the photos for themselves and do not show them or give them to anyone else").

${ }^{198}$ An Act Concerning Sexting, Pub. Act. No. 10-191, § 1, 2010 Conn. Acts (2010) (Reg. Sess.), available at http://www.cga.ct.gov/2010/ACT/PA/2010PA-00191-R00HB-05533-PA.htm (emphasis added).

${ }^{199}$ An Act Concerning Criminal Law, Act of July 19, 2010, Pub. Act. No. 096-1087, § 340(b), 2010 Ill. Laws (2010) (Reg. Sess.). available at http://www.ilga.gov/legislation/publicacts/fulltext.asp?Name=096-1087\&GA=96.

${ }^{200}$ Supra Part II, Section A.
} 


\section{E. Summary}

The analysis of the hypothetical sexting fact pattern above reveals some of the limitations of the four laws adopted in 2010. Only the sexting law of Arizona applies to Jill. Similarly, only the sexting law of Arizona applies to Jack's possession of Jill's image. Incredibly, none of the laws would appear to reach either Jack's hand-to-hand, hard copy distribution of Jill's image to his minor friends or the possession of Jill's image by Jack's friends.

\section{III. \\ CONCLUSION}

As lawmakers are scrambling today to draft new statutes like those examined in this article, featuring suitable and seemingly proportionate punishments for minors who engage in sexting, an even newer and more nefarious activity related to sexting apparently is on the rise "sextortion.",201 Sextortion, as described in an August 2010 newspaper article, is a phenomenon in which "teens who text nude cell phone photos of themselves or show off their bodies on the Internet are being contacted by pornographers who threaten to expose their behavior to friends and family unless they pose for more explicit porn, creating a vicious cycle of exploitation."202 In June 2010, for instance, 31-year-old Luis Mijangos of Orange County, California, allegedly victimized at least forty-four girls after he downloaded explicit photographs of scores of them and used those images to try to extort pornographic materials from them. ${ }^{203}$

Minors themselves can also commit sextortion. For instance, Anthony Stancl was sentenced to fifteen years in prison in February 2010 after he allegedly "posed as a girl on

${ }^{201}$ Charles Wilson, Feds: Online 'Sextortion' of Teens on Rise; Pornographers Contact Girls Who Post Explicit Photos and Threaten Them, LeDGER (Lakeland, Fla.), Aug. 15, 2010, at A1.

${ }^{202} \mathrm{Id}$.

${ }^{203}$ Andrew Blankstein, FBI Charges O.C. Man in 'Sextortion' Case, L.A. Times, June 23, 2010, at Metro Desk AA3. 
Facebook to trick male high school classmates into sending him nude cell phone photos, which he then used to extort them for sex."204 Stancel was a student at New Berlin Eisenhower High School in Waukesha, Wisconsin when he was accused in a criminal complaint of "persuading at least thirty-one boys to send him pictures of themselves naked and then blackmailing some of the boys into performing sex acts under the threat that the pictures would be released to the rest of the high school. ${ }^{, 205}$ Stancl's case is not an anomaly.

For example, in October 2009, a 14-year-old freshman at Whitnall High School in Greenfield, Wisconsin was "accused of coercing teen girls into sending him sexually explicit photos of themselves." 206 The boy allegedly "obtained nude photos by telling girls he would spread rumors about them." 207

Should such minors who allegedly engage in "sextortion" be treated like adults, subject to generally applicable extortion statutes, or should they be handled differently, as some states now are doing with minors who sext? While answering that question is beyond the scope of this article, the query nonetheless demonstrates the quickly shifting terrain on which the law rests when technology, teens and sex triangulate. Sexting laws like those described in this article undoubtedly will need to be amended as tech-savvy teens find other means of expressing - and exploiting - their own sexuality and that of other teens.

As this article has demonstrated, the low-tech, downstream transmission of hard copies of sexual images of minors - images that minors initially transmitted by cell phones- appears to escape the reach of the quartet of 2010 sexting laws examined in this article. Lawmakers in Arizona, Connecticut, Illinois and Louisiana may wish to amend their statutes to account for this

\footnotetext{
${ }^{204}$ Wilson, supra note 201, at A1.

${ }^{205}$ Mike Johnson, Stancl is Convicted of Assault, MilwaukeE J. Sentinel, Dec. 23, 2009, at B1.

${ }^{206}$ Tom Kertscher, Whitnall Student, 14, Accused of Forcing Girls to Send Nude Photos, MiLwAUKEE J. SENTINEL, Oct. 15, 2009, at B1. ${ }^{207}$ Id.
} 
apparent gap in their laws, while legislators in other states now considering bills targeting sexting, might also consider it.

The bottom line, as Professor Mary Graw Leary of the Columbus School of Law at Catholic University of America recently wrote, is that the "problem of self-produced child pornography is a complex one. ${ }^{208}$ When it come to punishing minors who produce their own child pornography, she observes that "proportionality is urged to be considered in light of the decreased moral culpability of minors and that their behavior is distinct from the pedophile or adult sexual predator of children."209

This line of logic would seem to embrace expanding the newly minted sexting laws to include low-tech, downstream recipients of hard-copy sexual images, such as Jack's friends in the hypothetical laid out earlier in this article. ${ }^{210}$ Without such an expansion prosecutors may be left with few alternatives other than either punishing them under generally applicable child pornography laws, replete with the stiff criminal sentences they carry, or giving them a legal free pass and a harsh verbal reprimand. Sexting laws provide prosecutors with a middle-ground option, and the more broadly those laws are drafted to cover the myriad situations that may stem or flow from an initial sexting incident, the more options prosecutors have in their legal tool kit.

This article also reveals a lack of uniformity across the sexting statutes adopted in 2010 by Arizona, Connecticut, Illinois and Louisiana. Such disparity creates an uneven patchwork of legislation that, the authors contend, fails to give minors proper notice of what sexting activities are permissible.

\footnotetext{
${ }^{208}$ Mary Graw Leary, Sexting or Self-Produced Child Pornography? The Dialog Continues - Structured Prosecutorial Discretion Within a Multidisciplinary Response, 17 VA. J. SoC. POL'Y \& L. 486, 497 (Spring 2010 ). ${ }^{209}$ Id. at 513.

${ }^{210}$ Supra Part II, Section A.
} 
For instance, even when it comes to what appears to be the most objective element of the offense of sexting - the maximum age of a possible perpetrator - there is disagreement. Two states (Arizona and Illinois) target those under eighteen years of age, one state (Louisiana) targets those under seventeen years of age and still another state - namely, Connecticut - adopts an even more nuanced, floor-and-ceiling age approach by providing that "no person who is thirteen years of age or older but under sixteen years of age may knowingly and voluntarily transmit by means of an electronic communication device a visual depiction of child pornography." 211

Another point of inconsistency is on the issue of affirmative defenses. While two states (Illinois and Louisiana) fail to specify any affirmative defenses, both Arizona and Connecticut provide one that appears to track or borrow from federal child pornography statutes. ${ }^{212}$

Other variations exist as well. Illinois' sexting statute only targets minors who send an image "of another minor," thus not covering self-sexters (minors who take and transmit photographs of themselves). In stark contrast, Connecticut's statute targets only self-sexters, while the laws of both Arizona and Louisiana cover both self-sexters and downstream-sexters. ${ }^{213}$

The commonality between the statutes, of course, is the punishment imposed, with none of the states treating the offense of sexting as a felony. Yet even here there are variations in the amount of possible fines and the length of jail time, if any, a minor faces for sexting. ${ }^{214}$

Ultimately, by the end of October 2010, only seven of the fifty states had adopted laws specifically designed to address sexting by minors as a separate criminal offense. ${ }^{215}$ Whether

\footnotetext{
${ }^{211}$ An Act Concerning Sexting, Pub. Act. No. 10-191, § 2, 2010 Conn. Acts (2010) (Reg. Sess.), available at http://www.cga.ct.gov/2010/ACT/PA/2010PA-00191-R00HB-05533-PA.htm (emphasis added).

${ }^{212}$ Supra Part I, Section D, Subsection 4.

${ }^{213}$ Supra Part I, Section A, Subsection 5.

${ }^{214}$ Supra Part I, Section C, Subsection 5.

${ }^{215}$ Supra notes $22-24$ and accompanying text (describing the sexting statutes adopted in 2009 by Utah, Nebraska and Vermont).
} 
uniformity or consistency begins to emerge, of course, remains to be seen as other states adopt laws that, perhaps, borrow aspects or include elements of the laws enacted in 2010 by Arizona, Connecticut, Illinois and Louisiana. This article has attempted to call attention to the differences, as well as to the strengths and weaknesses, of those laws by demonstrating their application to a realistic sexting scenario.

The authors readily acknowledge, however, that a single hypothetical fact pattern cannot possibly capture all of the multiple variations and nuances that exist when it comes to teen sexting. Lawmakers in states now considering sexting laws thus might request that their own staff attorneys tease out the different circumstances and situations under which sexting by minors might occur. Only by spotting and addressing the various permutations of sexting today can lawmakers better hope to deal with it tomorrow. In the mean time, however, the authors contend that those states with currently enacted sexting laws should amend them to account for the lowtech, downstream forwarding of such images by and to minors. 